UNIVERSIDADE DE SÃO PAULO

FACULDADE DE ECONOMIA, ADMINISTRAÇÃO E CONTABILIDADE DEPARTAMENTO DE ECONOMIA PROGRAMA DE PÓS-GRADUAÇÃO EM ECONOMIA

\title{
ARBITRAGE PRICING THEORY IN INTERNATIONAL MARKETS
}

Liana Oliveira Bernat

Orientador: Rodrigo D. L. S. Bueno, PhD

SÃO PAULO 
Prof. Dr. João Grandino Rodas

Reitor da Universidade de São Paulo

Prof. Dr. Reinaldo Guerreiro

Diretor da Faculdade de Economia, Administração e Contabilidade

Prof. Dr. Denisard Cnéio de Oliveira Alves

Chefe do Departamento de Economia

Prof. Dr. Pedro Garcia Duarte

Coordenador do Programa de Pós-Graduação em Economia 


\title{
ARBITRAGE PRICING THEORY IN INTERNATIONAL MARKETS
}

\author{
Dissertação apresentada ao Departamento de \\ Economia da Faculdade de Economia, \\ Administração e Contabilidade da \\ Universidade de São Paulo como requisito \\ para obtenção do título de Mestre Economia.
}

Orientador: Rodrigo D. L. S. Bueno

Versão Revisada

(versão original disponível na FEA-USP)

\section{SÃO PAULO}

2011

\footnotetext{
${ }^{1}$ A autora reconhece e agradece o financiamento da FAPESP.
} 


\section{FICHA CATALOGRÁFICA}

Elaborada pela Seção de Processamento Técnico do SBD/FEA/USP

Bernat, Liana Oliveira

Arbitrage pricing theory in international markets / Liana Oliveira Bernat.

-- São Paulo, 2011.

$51 \mathrm{p}$.

Dissertação (Mestrado) - Universidade de São Paulo, 2011.

Orientador: Rodrigo De Losso da Silveira Bueno.

1. Finanças internacionais 2. Econometria 3. Economia I. Universidade de São Paulo. Faculdade de Economia, Administração e Contabilidade II. Título.

CDD -332.042 
To my sister and best friend, Luiza, who was always ready to help me. 


\section{THANKS}

\section{AGRADECIMENTOS}

I tried to write thanks in English, but the only way to really express my feelings was using my native language.

Eu tentei escrever os agradecimentos em inglês para tentar manter a coerência, mas mais uma vez a coerência me abandonou. Prefiro expressar meus sentimentos na minha língua materna, até porque o mais importante é que todos os agradecidos entendam.

Agradeço muito (mas muito mesmo) aos meus pais por toda a ajuda que me deram ao longo dos últimos dois anos. Sem o apoio sentimental, moral e financeiro deles desde o início nada disso teria se realizado. Na verdade, eu não conseguiria nem ser aprovada na ANPEC se minha mãe não tivesse me acalmado na noite de insônia antes da prova. $\mathbf{E}$ nunca vou esquecer o dia em que cheguei muito frustrada com os meus esforços para terminar a dissertação e meu pai se ofereceu: - Você não quer explicar o problema da dissertação para mim? Quem sabe eu consigo te ajudar. Meus pais são médicos e é claro que até hoje eles não entenderam muito bem meu trabalho.

Agradeço minha irmã que, mesmo sendo estudante de veterinária, teve paciência de ler minha dissertação por mais de duas vezes e me ajudar na correção do inglês.

Agradeço ao meu orientador por ter sido ranzinza comigo todas as vezes que precisei e, principalmente, por ter me mostrado o caminho para chegar aqui.

Agradeço a todos os meus amigos, em especial à Carol, que não desistiram de mim, mesmo após todas às vezes nas quais troquei a companhia deles pela dos livros.

Expresso também que sou muito agradecida a todos os meus cachorros, que não podem compreender nada do que está escrito aqui, mesmo estando em português. Eles me fizeram companhia e esquentaram meus pés todas às vezes nas quais fiquei em casa estudando.

Enfim, agradeço a todos que conviveram comigo durante os últimos dois anos, à minha família, aos colegas de mestrado, ao financiamento da FAPESP e até ao meu namorado, que só conviveu comigo na fase final da elaboração desse trabalho, mas, que até agora, passou mais finais de semana longe de mim do que comigo para que eu conseguisse terminar a dissertação. 


\section{RESUMO}

Essa dissertação estuda o impacto de múltiplas fontes de riscos pré-especificados nos retornos de três grupos de países não sobrepostos, através de um modelo de Teoria de Precificação por Arbitragem (APT). Os grupos são compostos por mercados emergentes e desenvolvidos. Mercados emergentes tornaram-se importantes na economia mundial, especialmente como receptores de capital, mas não foram inclusos na maioria dos trabalhos correlatos anteriores. Duas estratégias foram adotadas para a escolha de dois conjuntos de fatores de risco. A primeira foi utilizar variáveis macroeconômicas, descritas na maior parte da literatura, como e excesso de retorno da carteira mundial, taxas de câmbio, variação da diferença entre a taxa de depósito em Eurodólar e a U.S. Treasury Bill (TED Spread) e mudanças no preço do petróleo. A segunda estratégia foi extrair fatores de risco através de uma análise de componentes principais, denominados fatores estatísticos. O primeiro resultado importante é a grande semelhança entre o primeiro fator estatístico e o retorno da carteira mundial. Nós estimamos o modelo APT usando duas metodologias estatísticas: Regressões Aparentemente não Correlacionadas Iteradas (ITNLSUR) de McElroy e Burmeister (1988) e o Método dos Momentos Generalizados (GMM) de Hansen (1982). Os resultados de ambas as metodologias são muito similares. Utilizando variáveis macroeconômicas, apenas o excesso de retorno da carteira mundial é precificado nos três grupos com prêmios variando de 4,4\% a $6.3 \%$ ao ano e, no modelo com variáveis estatísticas, apenas o primeiro fator estatístico é precificado em todos os grupos com prêmios que variam entre $6,2 \%$ a $8,5 \%$ ao ano. 


\begin{abstract}
This dissertation studies the impact of multiple pre-specified sources of risk in the return of three non-overlapping groups of countries, through an Arbitrage Pricing Theory (APT) model. The groups are composed of emerging and developed markets. Emerging markets have become important players in the world economy, especially as capital receptors, but they were not included in the majority of previous related works. Two strategies are used to choose two set of risk factors. The first one is to use macroeconomic variables, as prescribed by most of the literature, such as world excess return, exchange rates, variation in the spread between Eurodollar deposit tax and U.S. Treasury bill (TED spread) and change in the oil price. The second strategy is to extract factors by using a principal component analysis, designated as statistical factors. The first important result is a great resemblance between the first statistical factor and the world excess return. We estimate the APT model using two statistical methodologies: Iterated Nonlinear Seemingly Unrelated Regression (ITNLSUR) by McElroy and Burmeister (1988) and the Generalized Method Moments (GMM) by Hansen (1982). The results from both methods are very similar. With macroeconomic variables, only the world excess of return is priced in the three groups with a premium varying from $4.4 \%$ to $6.3 \%$ per year and, in the model with statistical variables, only the first statistical factor is priced in all groups with a premium varying from $6.2 \%$ to $8.5 \%$ per year.
\end{abstract}




\section{CONTENTS}

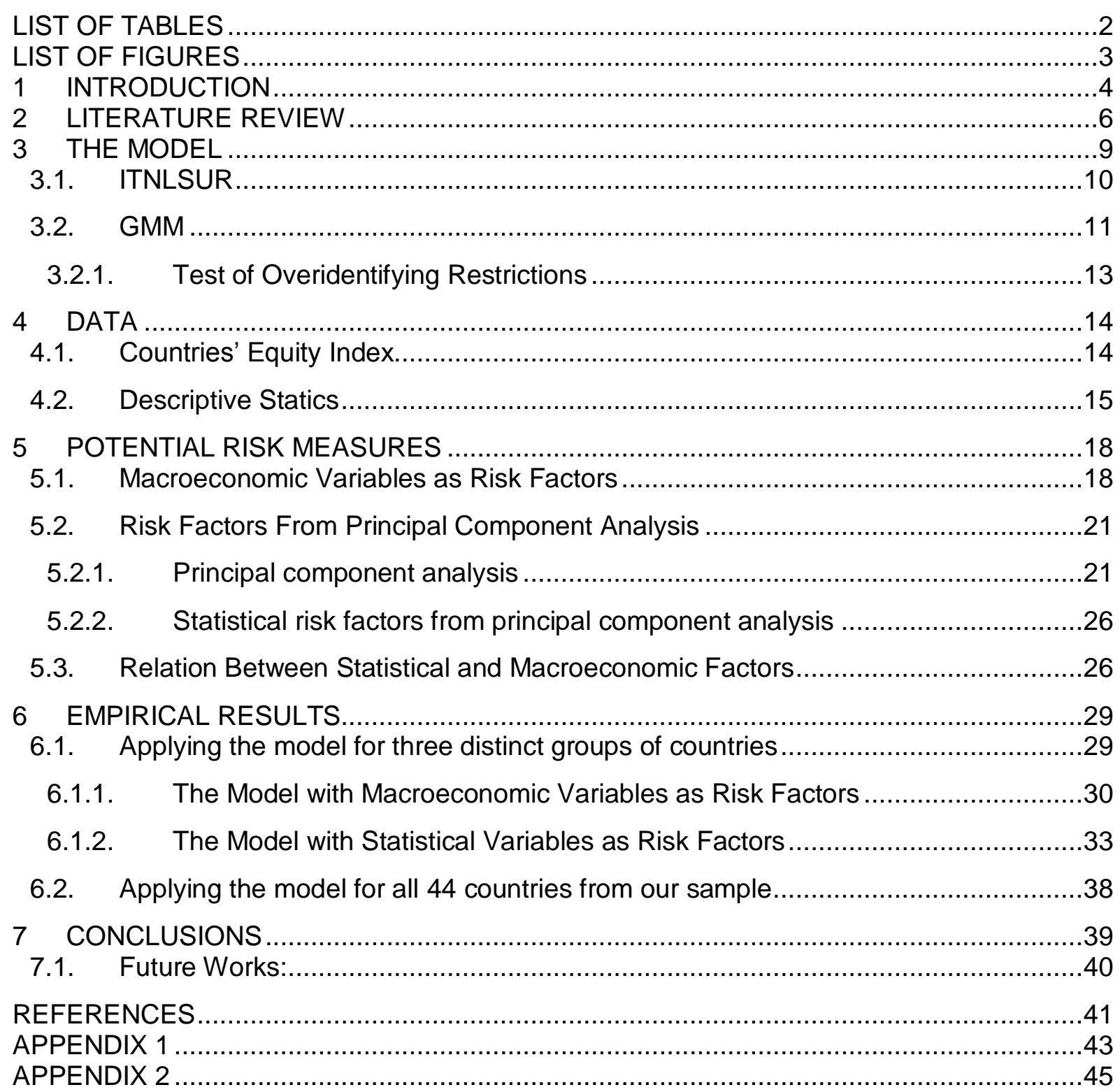




\section{LIST OF TABLES}

Table 1: Descripitive Statistics 16

Table 2: Mean Correlation of different sets of countries versus the world's portfolio returns 17

Table 3: Correlations' quantiles considering different sets of countries.

Table 4: First Five Eigenvectors and their Correlation with the Countries`Returns ...... 25

Table5: Descripitive Statisticals for Macroeconomic and Statistical Factors

Table6: Correlation Among Factors ................................................................ 27

Table7: Linear Projection of the Statistical Factors on the Macroeconomic Factors ............ 28

Table 8: Premia for the Macroeconomic Factors using Group 1................................. 31

Table 9: Premia for the Macroeconomic Factors using Group 2 .................................. 32

Table 10 Premia for the Macroeconomic Factors using Group 3 ................................. 33

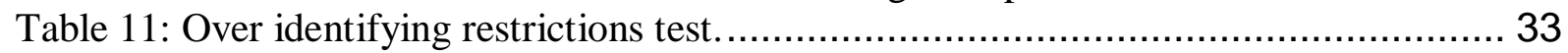

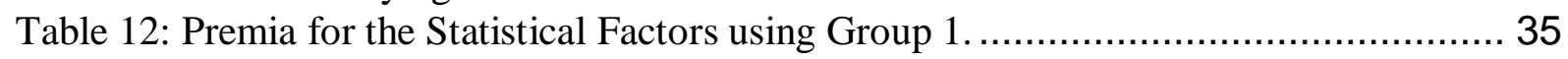

Table 13: Premia for the Statistical Factors using Group 2 .................................... 36

Table 14: Premia for the Statistical Factors using Group 3 ................................... 37

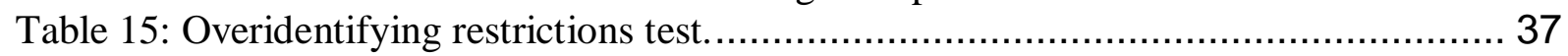

Table 16: Premia for the Macroeconomic Factors using 44 countries .......................... 38 


\section{LIST OF FIGURES}

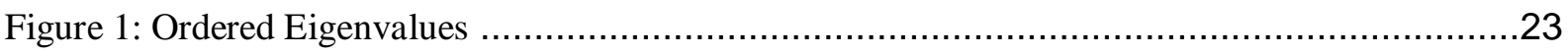

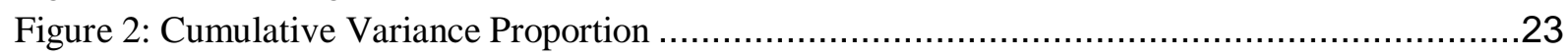

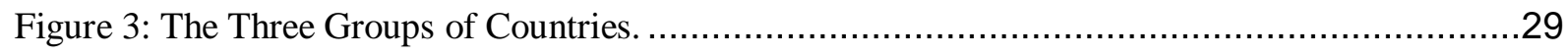

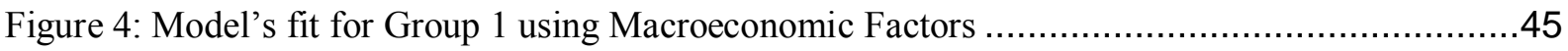

Figure 5: Model's fit for Group 2 using Macroeconomic Factors ...............................................46

Figure 6: Model's fit for Group 3 using Macroeconomic Factors ...........................................47

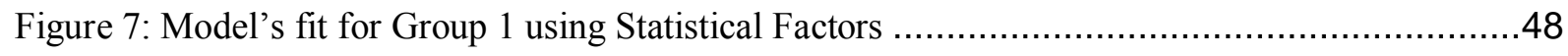

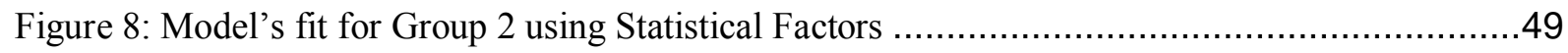

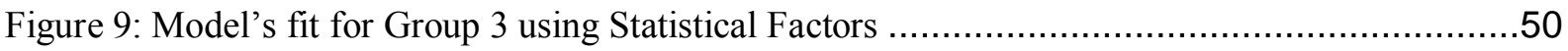

Figure 10: Model's fit for the 44 countries using Macroeconomic Factors......................................51 


\section{INTRODUCTION}

This work develops a study about the common sources of risk that impact changes in equity return of several different countries. A database from Morgan Stanley Capital International containing 24 developed markets, 16 emerging markets and 4 frontier ${ }^{1}$ markets from December 1992 to December 2009 is available. High economic development, great size and liquidity of the companies and ease market accessibility are what determine a country to be developed. Compared with the emerging countries, frontier markets present companies with lower size and liquidity and more difficult market accessibility. This is an original approach because, unlike previous related works, we are dealing with developed, emerging and frontier countries together. The last two groups of countries have gained importance in the world economic scene, especially as capital receptors from developed (and also emerging) markets.

In order to account for multiple sources of risk, an empirical analysis using the Arbitrage Pricing Theory (APT) model developed by Ross (1976) will be performed. The Iterated Nonlinear Seemingly Unrelated Regression (ITNLSUR) by McElroy and Burmeister (1988) and the Generalized Method of Moments by Hansen (1982) will be applied to estimate the average risk premia of the global sources of risk. Both methods are strongly consistent and asymptotically normal even in the absence of normal errors and they overcome the problems presented by the usual Two Step Procedure by Fama and Macbeth (1973). The Generalized Method of Moments is still advantageous by comprising the available information in the estimation process.

The main difficulty associated with the APT model is that the theory does not say anything about which risk factors should be included. Several empirical works focused on the attempt to determine them through two different strands: using pre-specified observed macroeconomic factors or assuming that, a priori, the factors were unknown. For equities from the United States economy, Roll and Ross (1980) adopted factor analysis to extract the risk factors. Chen, Roll and Ross (1986) and McElroy and Burmeister (1988) used

\footnotetext{
${ }^{1}$ Information about market classification framework is contained in: http://www.mscibarra.com/products/indices/global_equity_indices/gimi/stdindex/MSCl_Market_Classifi cation_Framework.pdf
} 
macroeconomic variables to estimate an APT applying different methodologies: the two step procedure from Fama and Macbeth and the ITNLSUR.

In a global framework, containing countries with so many disparities, it is even harder to imagine common sources of risk. Ferson and Harvey (1994) used pre-specified macroeconomic factors.

In order to better address such a problem, two sets of variables were treated as potential risk measures. The first set is composed of macroeconomic variables often prescribed by most of the asset pricing models literature ${ }^{2}$ such as excess return of the world portfolio, changes in the exchange rates, variation in the spread between Eurodollar deposit tax and U.S. Treasury bill (TED spread) and changes in oil price. The second group of potential risk measures was obtained following Campbell, Lo and MacKinlay (1997). For 44 countries equity returns in our database, a Principal Component Analysis were performed allowing us to compose five synthetic indices or portfolios pointing the directions of greatest variability of the original return data. That means, the first portfolio is in the direction of higher variance, the second portfolio is in the direction of second higher variance and so on. These synthetic portfolios are regarded as sources of risk and denominated statistical risk factors.

Then we investigate the relation among statistical and macroeconomic sources of risk. There is a great similarity between the factor extracted from the first principal component and the world excess return. For a robustness analysis, the countries were divided into three groups with similar geographic distribution and we calculated the risk premia for the statistical and macroeconomic factors separately. In general, only the world excess of return is priced in the model with macroeconomic variables, with a risk premium varying from $4.4 \%$ to $6.3 \%$ per year. In the model with statistical variables, only the first statistical factor is priced with a premium varying from $6.2 \%$ to $8.5 \%$ per year. Other variables can present significant risk premia, but the results are sensitive to the group and method of estimation considered. However, the inclusion of more variables tends to reduce the average pricing error.

This paper is organized as follows. Section 2 review the related literature; Section 3 presents the model and econometric methods; Section 4 describes the countries equity return data; Section 5 explains the choice for the potential risk measures; Section 6 presents our empirical results and in Section 7 we highlight our conclusions.

\footnotetext{
${ }^{2}$ For example Adler and Dumas (1983) and Ferson and Harvey (1993).
} 


\section{LITERATURE REVIEW}

Stephen Ross (1976) derived rigorously the Arbitrage Pricing Theory model (APT), whose starting premises are that markets are competitive and that individuals homogeneously believe that the return of all assets in the economy are driven by a linear structure of $\mathrm{k}$ risk factors.

In opposition to CAPM, APT allows for multiples risk factors, accounting for various sources of non-diversifiable risks. The market portfolio doesn't have any special importance and can or not be included as a risk factor. It's not necessary to assume any hypothesis related to the returns' distribution or the individuals' utility function. The model proposed by Ross, however, doesn't specify which the risk factors are. Several empirical works focused on the attempt to determine them through two different strands: using pre-specified observed macroeconomic factors or assuming that, a priori, the factors are unknown.

The empirical work of Roll and Ross (1980) adopted the second strand for equities from the United States economy. The authors use a statistical technique denominated Factor Analysis to extract the risk factors and estimate the sensitivity's coefficients. They conclude that at least three factors were important for pricing the assets. A clear interpretation for those risk factors isn't available, though. Also, an investigation about the return of individual variance revealed that, although expected returns are highly correlated with their respective variance, the variance itself doesn't add any explanatory power to the factors previously estimated in the APT.

Chen, Roll and Ross (1986) use macroeconomic variables to estimate an APT applying the two-pass methodology from Fama and Macbeth (1973). Based on financial theories they suggest the following variables: spread between long and short run interest rate, change in expected inflation, unexpected inflation, industrial production, spread between high and low grade bonds, market portfolio, aggregated consumption and oil price. However, only the first five variables turned out being significantly priced.

Still working with US data, McElroy and Burmeister (1988) employed a new methodology to estimate an APT with macroeconomic variables, the Iterated Nonlinear Seemingly Unrelated Regression (ITNLSUR), which will be further discussed in the Section 3 and presents several advantages over factor analysis and the Fama and Macbeth two-pass procedure. ITNLSUR 
overcomes the econometric problems of previous methodologies such as loss of efficiency, non uniqueness of the second step and unrobustness of the estimate if the errors are not normally distributed. The five macroeconomic factors adopted by McElroy and Burmeister were spread between 20 years government and corporate bonds portfolios, excess return of 20 years government bond portfolios over one month Treasury bill, an unexpected deflation series, an expected growth in sales and the S\&P 500 index. Although significant risk prices were found to all of them, the authors warn that there isn't justification for which or how many factors to use and nothing suggests the existence of just one set of variables with important role in asset pricing.

The APT model was also expanded to an international framework and this application is the one that will be used throughout this work. Solnik (1983) provides an analysis of the model developed by Ross (1976) when investors from different countries are considered. The author argues that the models of international asset pricing used by them were controversial due to different hypothesis for the utility function and sources of uncertainty. International Arbitrage Pricing Theory (IAPT) is an alternative, since it isn't based in any hypothesis about the utility function and only requires perfect capital market. The article shows that (1) every riskless portfolio will be riskless to any foreigner investor and (2) if the linear factor model holds in one given currency, it must also be valid in any arbitrarily currency chosen as numeraire.

Ikeda (1991) discusses the introduction of foreign exchange risk by adapting the APT model developed for closed economies for an international framework. The author concludes that if the return generation process is specified in a numeraire currency, the foreign exchange risk is automatically diversified away. Previous works of Solnik (1974), Stulz (1981) and Adler and Dumas (1983), however, stated that, under deviation from purchasing power parity, the foreign exchange rate must be priced.

Ferson and Harvey (1994) applied a multifactor model to study the cross section difference in the returns of sixteen OECD countries plus Singapore/Malaysia and Hong Kong. Several factors are included in an unconditional version of seemingly unrelated regression model and estimated by Hansen's (1982) Generalized Method of Moments. The authors came out to the conclusion that world market beta alone doesn't explain much of the difference among returns and that explanation power is added by a multifactor model. Besides, significant risk premia 
are encountered for the world return and for the trade-weighted U.S. dollar price of the currencies of 10 industrialized countries (G-10 index).

The empirical work of Harvey, Solnik and Zhou (2002) also applies the Generalized Method of Moments and uses return data from sixteen OECD countries plus Singapore/Malaysia and Hong Kong. They are interested, however, not only in explaining cross section differences but also in understanding the time variation in international assets return. They specify an information set to construct a conditional model with factors not pre-specified. The authors don't reject that at least two factors would be necessary to explain the conditional variance of the returns. The first factor is similar to the global market portfolio and the second factor would be related to foreign exchange risk.

Our contribution to this literature is to develop a robust study about the common sources of risk that impact changes in equity return of countries classified as developed, emerging and frontier. None of the previous related works have included these three classifications of countries together in a single analysis. Emerging and frontier markets have become important players in the world economy, especially as capital receptors from developed (and also emerging) markets. Due to this interaction among different economies around the world, we believe that there are common risk factors for these three kinds of markets.

We use two strategies to choose two sets of risk factors. The first set is composed by macroeconomic variables which, despite being based in the related literature, are arbitrary choice. The second group of risk factors, denominated statistical risk factors, is extracted by using principal component analysis. These factors represent the portfolios pointing the directions of greater variability for the 44 countries equity returns in our database and there is nothing arbitrary about them.

The particularity of our result is the following. With macroeconomic variables, only the world excess of return is priced. With statistical variables, only the first statistical factor is priced. And, although these two factors are a priori unrelated, they keep a significant relation between them. 


\section{THE MODEL}

Let countries' equity returns be driven by multiple risk factors and follow a multifactor Arbitrage Pricing Theory (APT) model. The main assumption of APT, formulated by Ross (1976), is that the difference between actual and expected returns on all assets are linearly related to a finite number of risk factors and that the number of assets in the economy is large relative to the number of factors. Then, if there are $n$ assets and $K$ risk factors, with $n>K$, the model can be written as:

$$
\begin{gathered}
R_{i}(t)=E_{t}\left[R_{i}(t)\right]+\sum_{J=1}^{K} \beta_{i j} f_{j}(t)+\varepsilon_{i}(t) \\
i=1, . ., n, \quad t=1, \ldots, T
\end{gathered}
$$

where $E_{t}\left[R_{i}(t)\right]$ is the expected return of country $i$ conditional to the information available at $t ; \beta_{i j}$ is the sensitivity of asset $i$ to $f_{j}(t)$, the $j$-th risk factor realization at time $t ; \varepsilon_{i}(t)$ is the idiosyncratic risk independent of the $K$ risk factors.

Under the restriction of no asymptotic arbitrage and some regularity conditions, the Arbitrage Pricing Theorem states that the expected return is approximated by the following relation:

$$
E_{t}\left[R_{i}(t)\right]=\lambda_{0}(t)+\sum_{J=1}^{K} \beta_{i j} \lambda_{j}(t)
$$

where, $\lambda_{j}(t)$ is the premium obtained by an investor for assuming the risk factor $j$. If there is a risk free asset in the economy and its return is known at time t, then $\beta_{i j}=0$ to all $j$, and $\lambda_{0}(t)$ can be regarded as the risk free return.

No asymptotic arbitrage condition is necessary instead of simple non arbitrage condition because each asset return has an idiosyncratic risk. If an asymptotic arbitrage opportunity exists, then, as $n$ gets larger, the idiosyncratic risk can be diversified away and it is possible to create a portfolio with the $\mathrm{n}$ risk assets that demands zero net investment and delivers close to a riskless return. 
The usual way to estimate the regression equation is using the two stage procedure proposed by Fama and MacBeth (1973). At first the $b_{i j}$ 's are estimated. If the factors are assumed as unknown, one can use factor analysis to extract the $b_{i j}$ 's. In the second stage, the $b_{i j}$ 's are treated as data in order to estimate the risk prices. To attenuate the error related to the second stage, the assets are grouped into portfolios. Some of the econometric problems associated to this methodology are loss of efficiency, non-uniqueness of the second step and unrobustness of the estimate if the errors are not normally distributed. These problems are avoided by the econometric methodologies presented below.

\subsection{ITNLSUR}

McElroy and Bumeister (1988) suggest an alternative method to estimate the risk sensitivities, $b_{i j}$ 's, and the risk prices, $\lambda_{j}$ 's, simultaneously. They assume that $\lambda_{1}, \ldots, \lambda_{j}$ do not vary over time. Second they substitute (2) into (1) and obtain:

$$
\begin{gathered}
R_{i}(t)-\lambda_{0}(t)=\sum_{J=1}^{K} \beta_{i j}\left(\lambda_{j}+f_{j}(t)\right)+\varepsilon_{i}(\mathrm{t}) \\
i=1, \ldots, n, \quad t=1, \ldots, T
\end{gathered}
$$

$\lambda_{0}(t)$, as already mentioned, will be assumed as the risk-free rate. The factors, $f_{j}, j=$ $1, \ldots, k$, are mean 0 . If a chosen factor doesn't have zero mean, $f_{j}$ will be the risk factor less it's mean.

To estimate the $N K \beta$ 's and the $K \lambda$ 's they use an iterated nonlinear seemingly unrelated regression method. It must be assumed that

$$
E_{t}\left[\varepsilon_{i}(t)\right]=0, \quad E_{t}\left[\varepsilon_{i}(t) \varepsilon_{j}(s)\right]=\left\{\begin{array}{ll}
\sigma_{i j} & t=s \\
0, & t \neq s
\end{array}, \quad E_{t}\left[\varepsilon_{i}(t) \mid f_{j}(s)\right]=0,\right.
$$

Then rewrite the system in a matrix form in terms of excess return.

$$
\begin{gathered}
\rho_{i}=\left[\boldsymbol{\lambda}^{\prime} \otimes \mathbf{1}_{\boldsymbol{T}}+\boldsymbol{F}\right] \beta_{i}+\varepsilon_{i}=\boldsymbol{X}(\boldsymbol{\lambda}) \beta_{i}+\varepsilon_{i}, \\
i=1, \ldots, N
\end{gathered}
$$


where $\rho_{i}$ is a $T x l$ vector of excess return, $\lambda$ is a $K x l$ vector of risk premiums, $\mathbf{1}_{T}$ is a $T x l$ vector of ones, $\boldsymbol{F}$ is a $T x K$ matrix of factors and $\beta_{i}$ is a $K x l$ vector of sensitivities.

Stacking the N equations, we get

$$
\left(\begin{array}{c}
\rho_{1} \\
\vdots \\
\rho_{N}
\end{array}\right)=\left[\begin{array}{ccc}
\boldsymbol{X}(\lambda) & \ldots & 0 \\
\vdots & \ddots & \vdots \\
0 & \ldots & \boldsymbol{X}(\boldsymbol{\lambda})
\end{array}\right]\left(\begin{array}{c}
\beta_{1} \\
\vdots \\
\beta_{N}
\end{array}\right)+\left(\begin{array}{c}
\varepsilon_{1} \\
\vdots \\
\varepsilon_{N}
\end{array}\right)
$$

Or, in matrix notation, $\rho=\left[I_{N} \otimes X(\lambda)\right] \boldsymbol{\beta}+\boldsymbol{\varepsilon}$

The NLSUR method follows three steps. At first step $\lambda$ is not identifiable, so $\lambda^{\prime} \beta_{i}$ is replaced by an intercept $\alpha_{i}, i=1, \ldots, N$, and one estimates $\theta_{i}=\left(\alpha_{i}, \beta_{i}\right)$ by OLS. This step is very similar to the first step of Fama and Macbeth(1973). However, we are not interested in making inference on the $\boldsymbol{\beta}^{\prime}$ s themselves, but rather in obtaining the residuals. In the second step, the residuals are used to estimate the covariance matrix $\hat{\Sigma}=T^{-1}\left(e_{i}{ }^{\prime} e_{j}\right)$. Finally, $(\boldsymbol{\lambda}, \boldsymbol{\beta})$ are taken as the parameters that minimize the following quadratic expression:

$$
Q(\lambda, \beta, \hat{\Sigma})=\left\{\rho-\left[I_{N} \otimes \boldsymbol{X}(\boldsymbol{\lambda})\right] \boldsymbol{\beta}\right\}^{\prime}\left(\hat{\Sigma}^{-1} \otimes I_{T}\right)\left\{\rho-\left[I_{N} \otimes \boldsymbol{X}(\boldsymbol{\lambda})\right] \boldsymbol{\beta}\right\},
$$

The third step can be iterated until convergence is reached. The residuals, obtained by substitution over the last $(\boldsymbol{\lambda}, \boldsymbol{\beta})$ estimated, are then used to update the covariance matrix and, iteratively, to obtain $(\lambda, \beta)$ from minimizing $\mathrm{Q}$. The ITNLSUR estimators are strongly consistent and asymptotically normal, despite the distribution of the errors. If the errors are normally distributed, then these estimators are also maximum likelihood estimators.

The ITNLSUR only accounts for heteroskedastic errors and disregards autocorrelation. However, under the efficient market hypothesis, only unexpected events aren't incorporated to the price, so the errors should be serially uncorrelated.

\subsection{GMM}

The Generalized Method of Moments by Hansen (1982) has a clear advantage over the ITNLSUR, since it allows the use of all available information in the estimation process. So we propose this alternative method of estimation to verify if the inclusion of the available information changes significantly the estimation results. 
Starting again from equation (3), we employ this method to estimate $\beta_{i j}$ and $\lambda_{j}, i=1, \ldots, N$, $J=1, \ldots, k$. As in the ITNLSUR, the GMM doesn't rely on any assumption about data distribution. It's rather based on the specification of moment conditions.

Consider equation (3), $\theta^{*}=\left(\lambda^{*}, \beta^{*}\right)$ as the real population parameter and $g($.$) an mx1 vector$ of real functions, the population moment conditions are:

$$
\begin{aligned}
E\left[g\left(w_{t}, \theta\right)\right] & =E\left[g\left(\rho(t), f(t), Z(t), \theta^{*}\right)\right]=E\left[\left(\rho(t)-\beta^{*}\left(\lambda^{*}+f(t)\right)\right) \otimes Z(t)\right] \\
& =[0]
\end{aligned}
$$

where, $\rho(t)$ is a Nx1 vector of excess returns, $\beta^{*}$ is $\mathrm{s} \mathrm{NxK}$ matrix of sensitivities of asset $\mathrm{i}$ to factor $\mathrm{j}, \lambda^{*}$ is a $\mathrm{Kx} 1$ vector of the risk premias, $f(t)$ is a $\mathrm{Kx} 1$ vector of the $\mathrm{k}$ factors' realization, $Z(t)$ is a vector of instruments that contains a constant, $f(t)$ and the variables that represent the available information set.

The sample counterpart of this moment condition is:

$$
g_{T}(w, \theta)=T^{-1} \sum_{t=1}^{T} g\left(w_{t}, \theta\right),
$$

The GMM estimator is defined as:

$$
\hat{\theta}^{G M M}=\operatorname{argmin}_{\theta} J_{T}(\theta)=g_{T}(w, \theta)^{\prime} W_{T} g_{T}(w, \theta)
$$

where $W_{T}$ is an mxm positive semi definite matrix that efficiently weights the moments. In order to make the estimation of the model possible, the number of moments should be equal or higher than the number of parameters.

Hansen (1982) showed that efficient estimators are obtained with $W_{T}$ equals the inverse of moment's long run covariance matrix. As this matrix isn't known, it must also be estimated. Among the ways to solve that, we chose the iterated GMM. By this approach, we start with $\widehat{W_{T}}$ equals to the identity matrix and solve for the parameters. Next, using a consistent method, the parameters from the first step are used in the estimation of the covariance matrix. These two steps are repeated until convergence is reached. 
Unlike ITNLSUR, depending on the choice of $\widehat{W}_{T}$, GMM allows one to deal with heteroskedastic, contemporaneous correlated and serially autocorrelated errors. However, because of the efficient market's assumption and the GMM's poor performance in small sample, autocorrelation isn't going to be treated here. Newey- West covariance matrix with no lags is used to construct the weighting matrix robust to heteroskedasticity and contemporaneous correlation of unknown form in the following way:

$$
\widehat{\Omega}_{w}=\frac{1}{T-N} \sum_{t=1}^{T} g\left(w_{t}, \theta\right) g\left(w_{t}, \theta\right)^{\prime},
$$

\subsubsection{Test of Overidentifying Restrictions}

Since the number of moments exceeds the number of parameters, the estimated moments won't all equal zero. We can perform an overidentification test, introduced by Hansen (1982), to evaluate whether the moments are sufficiently close to zero. 


\section{DATA}

\subsection{Countries' Equity Index}

The equity indices for all the countries considered here are calculated by the Morgan Stanley Capital International (MSCI). These indices are measured in US dollar, monthly, with dividends reinvestments in excess of the 30 day Treasury Bill, assumed as the proxy for the risk free asset.

MSCI indices are designed to represent the opportunity set for international investor. The methodology does not vary across countries and the following characteristics favor its composition according to diversification principles: it doesn't have controlled and controllers in the same portfolio; the composition is free float adjusted market capitalization weighted; one sector can`t overcome more than $30 \%$ of the portfolio composition.

Unlike most researches, we will consider not only developed markets, but also emergent and frontier markets. All the equity indices available by MSCI from December 1992 to December 2009 will be used. This results in 24 developed markets, 16 emerging markets and 4 frontier markets $^{3}$. The three non-overlapping categories of country classification - frontier, emergent or developed - are held by MSCI, following criteria of economic development, size and liquidity and market accessibility. The classification is annually revised.

MSCI also disposes a value weighted equity index of 24 developed markets and 21 emergent markets, named MSCI All Country World Index. We will use such index as the market portfolio, as Section 5 describes.

\footnotetext{
${ }^{3}$ The 24 developed markets that we will use are Australia, Austria, Belgium, Canada, Denmark, Finland, France, Germany, Greece, Hong-Kong, Ireland, Israel, Italy, Japan, Netherland, New Zealand, Norway, Portugal, Singapore, Spain, Sweden, Switzerland, United Kingdom and United States. The 19 emerging markets are Brazil, Chile, China, Colombia, India, Indonesia, Korea, Malaysia, Mexico, Peru, Philippines, Poland, South Africa, Taiwan, Thailand and Turkey. The 4 frontier markets are Argentina, Jordan, Pakistan and Sri Lanka.
} 


\subsection{Descriptive Statics}

Table 1 presents annualized mean, annualized standard deviation ${ }^{4}$ and autocorrelation of the logarithm return ${ }^{5}$, in excess of the 30-day Treasury Bill, for each country and world portfolio. The significant autocorrelations are marked with an $\left(^{*}\right)$. It's Interesting to note that, while standard deviations for developed countries vary from $15 \%$ to $35 \%$, the standard deviation of emerging ones vary from $19 \%$ to $57 \%$. Brazil has the highest mean return (15.98\%) with standard deviation of $41.06 \%$. Turkey has the highest standard deviation (56.68\%) with return of $10.78 \%$. The United States have the smallest standard deviation (15.37\%) with a $4.16 \%$ return. Five countries - Ireland, Japan, China, Philippines and Thailand - have negative mean returns during the analyzed period. Twenty of the forty four countries present significant autocorrelation of first order, but the number of countries with higher order significant autocorrelations is considerably lower.

At APPENDIX 1 we show the correlation matrix for the equity index and the world portfolio. We summarize some features of the correlation in Table 2 and Table 3. Most of the countries present high correlation with the world's return which is justified by the way the portfolio is constructed. However, even the frontier markets, that are not part of the index, present a nearly $30 \%$ mean correlation with the world's portfolio. As is shown in Table 3, the correlation among developed markets is much higher than the correlation among emerging markets and the correlation between emerging and developed markets.

\footnotetext{
${ }^{4}$ The annualized mean $\left(\overline{R_{A}}\right)$ and annualized standard deviation $\left(\overline{S D_{A}}\right)$ of monthly return are calculated as follows:

$\overline{R_{A}}=12 * \overline{R_{M}}$ and $\overline{S D_{A}}=\sqrt{12} * \overline{S D_{M}}$, where $\overline{R_{M}}$ is the arithmetical mean of monthly returns and $\overline{S D_{M}}$ is the standard deviation of monthly returns.

${ }^{5}$ The excess logarithm returns are calculated monthly as $\ln \left(\frac{I_{t}}{I_{(t-1)}}\right)-\ln \left(\frac{T B i l_{t}}{T B i l_{(t-1)}}\right)$, where $I_{t}$ represents the MSCI Index for a given country in time $t$ and TBill $_{t}$ is the index for 30-day Treasury BILL.
} 
Table 1: Descripitive Statistics

\begin{tabular}{|c|c|c|c|c|c|c|c|c|}
\hline Index & Mean & $\begin{array}{l}\text { Standard } \\
\text { Deviation }\end{array}$ & p1 & $\rho 2$ & $\rho 3$ & $\rho 4$ & م12 & $\rho 24$ \\
\hline WORLD & $3.87 \%$ & $15.80 \%$ & $0.185^{*}$ & 0.012 & 0.094 & $0.118^{*}$ & 0.048 & 0.026 \\
\hline \multicolumn{9}{|l|}{ Developed } \\
\hline AUSTRALIA & $8.33 \%$ & $20.80 \%$ & 0.105 & 0.051 & 0.118 & 0.056 & -0.033 & 0.043 \\
\hline AUSTRIA & $1.91 \%$ & $25.58 \%$ & $0.282 *$ & $0.177 *$ & 0.086 & $0.145 *$ & k 0.048 & 0.006 \\
\hline BELGIUM & $3.71 \%$ & $22.91 \%$ & $0.325 *$ & 0.032 & 0.025 & $0.225 *$ & 0.043 & 0.013 \\
\hline CANADA & $8.09 \%$ & $21.47 \%$ & $0.167 *$ & * 0.058 & 0.035 & 0.051 & -0.084 & -0.051 \\
\hline DENMARK & $8.79 \%$ & $20.05 \%$ & 0.110 & -0.003 & 0.123 & 0.087 & -0.051 & 0.017 \\
\hline FINLAND & $12.52 \%$ & $34.49 \%$ & $0.191 *$ & $* \quad-0.075$ & 0.062 & 0.006 & 0.040 & 0.160 \\
\hline FRANCE & $5.24 \%$ & $19.98 \%$ & $0.132 *$ & $*-0.053$ & 0.036 & 0.116 & 0.075 & 0.091 \\
\hline GERMANY & $5.47 \%$ & $23.19 \%$ & 0.075 & 0.037 & 0.000 & 0.084 & 0.117 & 0.064 \\
\hline GREECE & $4.90 \%$ & $31.10 \%$ & 0.141 & 0.025 & 0.039 & 0.129 & -0.019 & 0.015 \\
\hline HONG KONG & $5.54 \%$ & $27.61 \%$ & 0.114 & 0.036 & -0.056 & -0.060 & -0.149 & 0.003 \\
\hline IRELAND & $-0.21 \%$ & $22.41 \%$ & $0.292 *$ & $0.161 *$ & $0.184 *$ & $0.132 *$ & k $\quad 0.078$ & -0.023 \\
\hline ISRAEL & $4.49 \%$ & $25.00 \%$ & 0.082 & 0.002 & 0.005 & -0.006 & -0.062 & -0.081 \\
\hline ITALY & $5.19 \%$ & $23.61 \%$ & 0.055 & -0.075 & 0.063 & $0.173 *$ & k 0.145 & 0.075 \\
\hline JAPAN & $-2.42 \%$ & $20.27 \%$ & $0.181 *$ & $* \quad-0.047$ & $0.148 *$ & 0.041 & 0.000 & -0.107 \\
\hline NETHERLANDS & $6.20 \%$ & $20.74 \%$ & 0.099 & 0.008 & 0.015 & $0.140 *$ & 0.098 & 0.108 \\
\hline NEW ZEALAND & $4.78 \%$ & $23.31 \%$ & 0.010 & -0.008 & $0.231 *$ & 0.097 & 0.060 & 0.060 \\
\hline NORWAY & $8.53 \%$ & $27.56 \%$ & $0.175 *$ & * 0.030 & 0.106 & -0.032 & -0.118 & -0.047 \\
\hline PORTUGAL & $6.01 \%$ & $22.41 \%$ & $0.137 *$ & * -0.002 & 0.055 & 0.030 & -0.034 & -0.049 \\
\hline SINGAPORE & $4.01 \%$ & $27.50 \%$ & 0.105 & 0.111 & -0.017 & 0.083 & 0.029 & -0.031 \\
\hline SPAIN & $10.43 \%$ & $22.95 \%$ & 0.083 & -0.068 & 0.057 & 0.084 & -0.005 & -0.058 \\
\hline SWEDEN & $9.52 \%$ & $27.13 \%$ & 0.101 & -0.018 & $0.181 *$ & 0.080 & 0.002 & 0.076 \\
\hline SWITZERLAND & $7.49 \%$ & $16.88 \%$ & $0.146 *$ & $*-0.053$ & 0.056 & 0.028 & 0.019 & 0.109 \\
\hline UNITED KINGD & $4.00 \%$ & $15.59 \%$ & $0.242 *$ & * 0.100 & 0.075 & $0.191 *$ & 0.044 & 0.027 \\
\hline USA & $4.16 \%$ & $15.37 \%$ & $0.120 *$ & $* \quad-0.013$ & $0.125 *$ & 0.091 & 0.097 & 0.032 \\
\hline \multicolumn{9}{|l|}{ Emerging } \\
\hline BRAZIL & $15.98 \%$ & $41.06 \%$ & 0.075 & 0.056 & -0.065 & 0.026 & 0.037 & -0.053 \\
\hline CHILE & $7.55 \%$ & $24.70 \%$ & $0.120 *$ & $*-0.001$ & -0.076 & $0.175 *$ & k 0.023 & -0.033 \\
\hline CHINA & $-3.72 \%$ & $37.57 \%$ & $0.115 *$ & * 0.097 & -0.100 & -0.082 & -0.076 & -0.075 \\
\hline COLOMBIA & $12.59 \%$ & $33.35 \%$ & $0.204 *$ & * -0.025 & -0.026 & 0.082 & 0.038 & 0.096 \\
\hline INDIA & $7.27 \%$ & $31.60 \%$ & $0.134 *$ & * $0.136 *$ & -0.033 & 0.070 & 0.003 & 0.093 \\
\hline INDONESIA & $3.21 \%$ & $48.54 \%$ & $0.214 *$ & $* \quad-0.086$ & 0.027 & $0.174 *$ & ${ }^{k}-0.122$ & 0.019 \\
\hline KOREA & $4.35 \%$ & $40.02 \%$ & 0.094 & 0.004 & 0.087 & -0.037 & -0.047 & 0.017 \\
\hline MALAYSIA & $1.82 \%$ & $31.72 \%$ & $0.200 *$ & $0.277 *$ & -0.011 & 0.026 & -0.005 & 0.032 \\
\hline MEXICO & $6.35 \%$ & $32.74 \%$ & 0.111 & 0.062 & 0.055 & -0.042 & -0.028 & 0.006 \\
\hline PERU & $14.31 \%$ & $33.92 \%$ & -0.006 & 0.002 & 0.007 & 0.078 & -0.069 & -0.072 \\
\hline PHILIPPINE & $-2.30 \%$ & $32.71 \%$ & $0.168 *$ & 0.082 & -0.033 & 0.008 & $0.116^{*}$ & -0.091 \\
\hline POLAND & $11.54 \%$ & $46.71 \%$ & 0.100 & 0.033 & 0.119 & -0.002 & -0.066 & -0.030 \\
\hline SOUTH AFRICA & $8.64 \%$ & $28.75 \%$ & 0.039 & -0.036 & -0.008 & -0.015 & 0.018 & -0.142 \\
\hline TAIWAN & $1.97 \%$ & $31.91 \%$ & 0.076 & $0.121 *$ & -0.071 & -0.046 & -0.024 & 0.075 \\
\hline THAILAND & $-2.59 \%$ & $42.09 \%$ & 0.011 & $0.157 *$ & -0.014 & -0.084 & 0.086 & -0.113 \\
\hline TURKEY & $10.78 \%$ & $56.68 \%$ & 0.048 & -0.012 & 0.087 & -0.046 & 0.002 & -0.020 \\
\hline \multicolumn{9}{|l|}{ Frontier } \\
\hline ARGENTINA & $3.31 \%$ & $40.03 \%$ & 0.074 & 0.074 & 0.010 & 0.067 & -0.069 & 0.025 \\
\hline JORDAN & $2.34 \%$ & $19.62 \%$ & $0.262 *$ & 0.114 & $0.119 *$ & $0.124 *$ & ${ }^{k}-0.029$ & 0.078 \\
\hline PAKISTAN & $1.38 \%$ & $41.54 \%$ & 0.049 & 0.037 & -0.050 & 0.071 & -0.019 & 0.078 \\
\hline SRI LANKA & $2.60 \%$ & $36.07 \%$ & 0.102 & $0.132 *$ & -0.010 & 0.076 & 0.002 & 0.017 \\
\hline
\end{tabular}


Table 2: Mean Correlation of different sets of countries versus the world's portfolio returns

\begin{tabular}{lc}
\hline \multicolumn{2}{c}{$\begin{array}{c}\text { Mean Correlation } \\
\text { World Portfolio vs. }\end{array}$} \\
\hline \hline (1) All countries & $64.0 \%$ \\
(2) Only Developed & $75.8 \%$ \\
(3) Only Emerging and Frontier & $49.8 \%$ \\
(4) Only Emerging & $54.8 \%$ \\
(5) Only Frontier & $29.6 \%$
\end{tabular}

Table 3: Correlations' quantiles considering different sets of countries.

\begin{tabular}{|c|c|c|c|c|c|c|c|c|c|}
\hline \multicolumn{10}{|c|}{ Correlations' Quantiles } \\
\hline Considering: & $1 \%$ & $5 \%$ & $10 \%$ & $25 \%$ & $50 \%$ & $75 \%$ & $90 \%$ & $95 \%$ & $99 \%$ \\
\hline (1) All countries & $8.0 \%$ & $17.9 \%$ & $23.8 \%$ & 35.5\% & $44.5 \%$ & "56.4\% & $66.9 \%$ & $73.0 \%$ & $79.8 \%$ \\
\hline (2) Only Developed & $29.3 \%$ & $39.8 \%$ & $44.3 \%$ & $52.3 \%$ & $61.5 \%$ & $69.6 \%$ & $75.5 \%$ & $78.5 \%$ & $87.7 \%$ \\
\hline (3) Only Emerging and Frontier & $9.2 \%$ & $13.5 \%$ & $19.1 \%$ & $26.6 \%$ & $37.0 \%$ & $46.1 \%$ & $55.3 \%$ & $59.1 \%$ & $64.2 \%$ \\
\hline
\end{tabular}




\section{POTENTIAL RISK MEASURES}

It's not an easy task to imagine which global risk factors can influence the return variation of different countries. In the attempt to do so, we try two approaches. The first one is to apply the same macroeconomic factors suggested by earlier works, which were only made using more restrictive and more similar countries. The second approach involves constructing the factors from principal component analysis.

\subsection{Macroeconomic Variables as Risk Factors}

Here we expose the macroeconomic variables used throughout this research as risk factors that drive the movement on the countries' equity returns. All of them are available from January 1993 to December 2009 and measured monthly. The choice of each variable is reasoned in the relevant literature.

\section{i. Market Portfolio Return}

The market portfolio in our case is a world portfolio. MSCI available the All Country World Index, a market value weighted equity index of 24 developed markets and 21 emergent markets ${ }^{6}$. Notice that the four frontier markets included in this research - Argentina, Jordan, Pakistan and Sri Lanka - don't participate in the composition of the World Index. The considerations about the calculation's methodology are the same that were made for the countries equity index. The return in the world index in excess of the one month Treasury bill will be the macroeconomic variable adopted.

In many asset pricing models, the market portfolio is included as a potential risk measure. The Capital Asset Pricing Model (CAPM) developed by Sharpe (1964), Lintner (1965) and Treynor (1961) can be understood as a particular case of the Arbitrage Pricing Model in which the risk premium of each asset is only related to the excess return of the market portfolio. To the American market, Fama and French (1993) created a three factor model, including a market portfolio with significant risk premia. In an international framework, Harvey (1991) doesn't reject an unconditional version of CAPM. Ferson and Harvey

\footnotetext{
${ }^{6}$ The 24 developed markets are the same described in the previous footnote. The 21 emerging market are those described in the previous footnote plus Chez Republic, Egypt, Hungary, Morocco, Russia.
} 
$(1993,1994)$ infer a significant risk premium for the world portfolio in the presence of multiple factors.

\section{ii. Foreign Exchange Risk}

The Federal Reserve Board calculates two non-overlapping weighted indexes of real exchange rates. The weights are based on the trading volume with the United States ${ }^{7}$. The Major Currencies Index ${ }^{8}$ encompasses seven currencies that are largely traded outside their internal markets. The Other Important Trading Partners Index (OITP Index) ${ }^{9}$ is composed by 19 currencies, essentially from Asian and Latin America emerging countries. The logarithm variation of those indices will be included as macroeconomic variables for the following reasons.

According to the models of Solnik(1974), Stulz(1981) and Adler and Dumas (1983), under deviations from purchasing power parity, the foreign exchange risk must be priced. In Adler and Dumas (1983), returns in a reference currency are driven not only by the covariance with the market portfolio return but also by the covariance with the inflations' variation, in the reference currency, of all countries under consideration. Inflation in the reference currency can be decomposed into local inflation plus the variation in the nominal exchange rate. If the local inflation is stable, then inflation in the reference currency can be approximated by the variation in the nominal exchange rate. However, as our sample contains emerging and frontier markets, considering local inflation stable isn't reasonable. So, we follow the suggestion of Carrieri, Errunza, Majerbi (2004) that, if the inflation in the reference currency is stable, a better approximation would be the real exchange rate. This can be better understood by the formulation bellow.

Let US Dollar be our reference currency and $e_{i t}^{R}$ be the real exchange rate in (US dollar $\$) /($ currency of country I \$).

$$
e_{i t}^{R}=e_{i t} \times \frac{P_{i t}}{P_{t}}
$$

\footnotetext{
7 The methodology of the Index calculation is detailed in "Index of Foreign Exchange Value of the Dollar", Federal Reserve Bulletin, Winter 2005.

8 The included currencies are from Euro area countries, plus Canada, Japan, United Kingdom, Switzerland, Australia and Sweden.

${ }^{9}$ The other important partners are China, Mexico, South Korea, Taiwan, Malaysia, Singapore, Brazil, Thailand, India, Philippines, Israel, Indonesia, Russia, Saudi Arabia, Chile, Argentina, Colombia and Venezuela.
} 
where, $e_{i t}$ is the nominal exchange rate, $P_{t}$ is the price level in the United States and $P_{i t}$ is the price level of country $i$.

The inflation of country $i$ in the US dollar reference, $\pi_{i t}^{U S \$}$, is

$$
\pi_{i t}^{U S \$}=\Delta \ln \left(e_{i t} \times P_{i t}\right)=\Delta \ln \left(e_{i t}^{R} \times P_{t}\right)=\Delta \ln \left(e_{i t}^{R}\right)+\pi_{U S t},
$$

and $\pi_{U S t}$ is the inflation in the US.

Thus, if the inflation in the reference currency is reasonably stable, we can approximate inflation of country $i$ in the reference currency by the variation in the real exchange rate.

The 44 countries of our base, using US as reference, would demand the inclusion of 43 real exchange rates. Empirically, this is very complex to implement. The aggregated indices provided by the Federal Reserve give the model tractability. The real OITP and Major indices formulation is

$$
I_{t}^{R}=I_{t-1}^{R} \times \prod_{i=1}^{N(t)}\left(\frac{x_{i t}^{R}}{x_{i t-1}^{R}}\right)^{w_{i t}}
$$

where $I_{t-1}^{R}$ is the index real value in $\mathrm{t}-1, w_{i t}$ is the weight of currency $\mathrm{i}$ in $\mathrm{t}, \mathrm{N}(\mathrm{t})$ is the number of currencies that composes the index in $\mathrm{t}$ and $x_{i t}^{R}$ is the American dollar price in terms of the foreign currency from country $i$ in (currency of country i \$ )/(US Dollar \$) at time t. Notice that $x_{i t}^{R}=1 / e_{j t}^{r}$. So, for Major and OITP indices, we will use $\ln \left(\frac{I_{t-1}^{R}}{I_{t}^{R}}\right)=\sum_{i=1}^{N(t)} w_{i t} \Delta \ln \left(e_{i t}^{R}\right)$ as the macroeconomic measure that approximates aggregated inflation for a group of countries.

\section{iii. TED Spread}

Another macroeconomic variable included in our study is the change in the spread between the 90 days Eurodollar deposit Tax, represented by LIBOR, and the 90 day U.S. Treasury bill yield. This measure is known as TED spread and can be considered an indicator of global risk credit. LIBOR is the tax offered for commercial banks' loans, while the U.S. treasury is the proxy for the risk free. Changes in the spread would reflect alterations in the risk of nonpayment of interbank loans. 


\section{iv. Oil Price}

The monthly variation in the oil price in U.S. dollar per barrel (FMI/IFS), in excess of the one month Treasury bill, will be the last macroeconomic variable included in our study. This factor is suggested in Chen, Roll and Ross (1986) for the American market. The authors' conclusion, however, is that the risk premium for the variation in the oil price isn't significant for two of the three analyzed periods. Wayne and Ferson (1994) don't find a significant price error for the variation in the oil price in a study that only considered developed countries.

\subsection{Risk Factors From Principal Component Analysis \\ 5.2.1. Principal component analysis}

In our work we are interested in the common factors that have impact in the return's movement of several different countries. In the attempt to identify these factors we will apply to our sample of 44 countries a Principal Component Analysis.

This technique consists of rewriting the sample in order to explain its variance-covariance structure. Algebraically, we will be rotating the original data through a new set of orthogonal axes. These axes represent the directions of greater variability and are designated Principal Components. The first Principal Component accumulates the higher variance, the second Principal Component, the second higher variance and so on.

To describe the total system variability it would be necessary as many Components as present variables in the system. In our case, the 44 country equity returns would require the use of 44 Components. In general, however, a small set of Principal Components accounts for a substantial part of this variability. This allows us to work with reduced dimensionality.

The Principal Component Analysis doesn't rely on any hypothesis about the variables' joint distribution and is only based on the covariance structure of the data. This technique is frequently mistaken with Factor Analysis. Despite of the resemblances presented in both methodologies, Factor Analysis imposes questionable restrictions on the data.

Actually, is very simple to determine the Principal Components ${ }^{10}$ based on the following property. Let $R^{\prime}=\left[R_{1}, R_{2}, \ldots, R_{n}\right]$ be a vector of the $\mathrm{n}$ variables that integrate the system (the

\footnotetext{
${ }^{10}$ For more information see Johnson and Wichern (2007).
} 
44 country equity returns) and $\Sigma$ be the covariance matrix of $R^{\prime}$. And let $\left(\lambda_{1}, e_{1}\right),\left(\lambda_{2}, e_{2}\right), \ldots,\left(\lambda_{n}, e_{n}\right)$ be the pairs of eigenvalues-eigenvectors of $\Sigma$, such that $\lambda_{1} \geq$ $\lambda_{2} \geq \cdots \geq \lambda_{n} \geq 0$. So, the ith Principal Component is given by:

$$
Y_{i}=e_{i}^{\prime} R, \quad i=1,2, \ldots n
$$

In this case,

$$
\begin{gathered}
\operatorname{Var}\left(Y_{i}\right)=e_{i}^{\prime} \Sigma e_{i}=\lambda_{i}, \quad i=1,2, \ldots, n \\
\operatorname{Cov}\left(Y_{i}, Y_{j}\right)=0, \quad i \neq j
\end{gathered}
$$

Other important property is that the sum of the variances of the original data is equal the sum of the eigenvalues. Thus,

$$
\sigma_{11}+\sigma_{22}+\cdots+\sigma_{n n}=\sum_{i=1}^{n} \operatorname{Var}\left(R_{i}\right)=\lambda_{1}+\lambda_{2+\cdots}+\lambda_{n}=\sum_{i=1}^{n} \operatorname{Var}\left(Y_{i}\right)
$$

And the proportion of the total population's variance due to ith Component is:

$$
\frac{\lambda_{i}}{\lambda_{1}+\lambda_{2}+\cdots+\lambda_{n}}, \quad i=1,2, \ldots n
$$

\section{Application}

The described methodology will be applied to the countries' equity returns in excess of the one-month Treasury bill. Using the notation of the previous section to our data, $R^{\prime}=$ $\left[R_{1}, R_{2}, \ldots, R_{44}\right]$ is a matrix 44 by 204 , representing the returns of the 44 countries from January 1993 to December 2009. $\Sigma=\operatorname{Var}(R)$ is a 44 by 44 matrix of covariance with the pairs of eigenvalues-eigenvectors $\left(\lambda_{1}, e_{1}\right),\left(\lambda_{2}, e_{2}\right), \ldots,\left(\lambda_{44}, e_{44}\right)$, such that $\lambda_{1} \geq \lambda_{2} \geq \cdots \geq$ $\lambda_{44} \geq 0$. Finally, the Principal Components, $Y_{i}=e_{i}^{\prime} R$, are vectors of size $\mathrm{t}=204, i=$ $1, \ldots, 44$.

The first step is to determine how many Components are necessary to describe a reasonable amount of the sample's variability and reduce the dimensionality. This question doesn't have a closed answer. However, an analysis based on the magnitude of the eigenvalues and on the 
proportion of the explained variability can support this decision. Figure 1 shows the graph of the ordered eigenvalue's magnitudes. Around the fifth eigenvalue the difference between successive eigenvalues is already reduced to near 0.02 or less, and the magnitudes themselves are relatively close to zero if compared to the value of the first eigenvalue $(0.150)$. Figure 2 shows that the first Component alone explains around $44 \%$ of the variability of the data and that around $65 \%$ is accumulated by the first five Components. Additional Components marginally contribute with very small variance's proportion. Considering what was exposed, five Components will be adopted as describing a fair amount of the sample's variability.

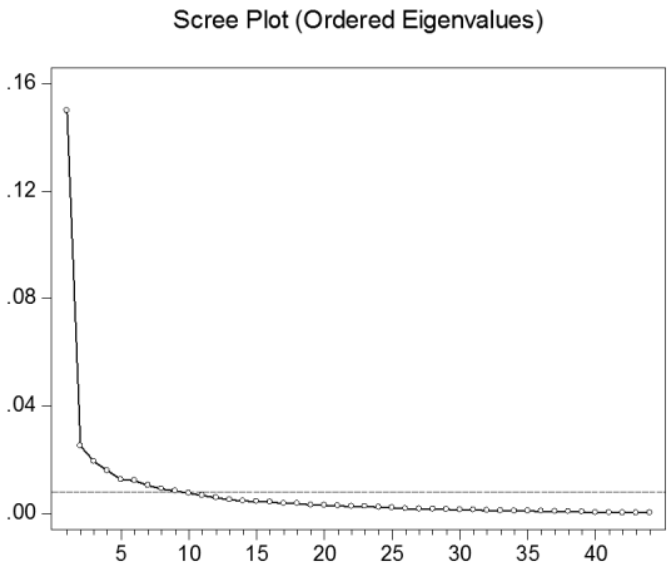

Figure 1: Ordered Eigenvalues

Eigenvalue Cumulative Proportion

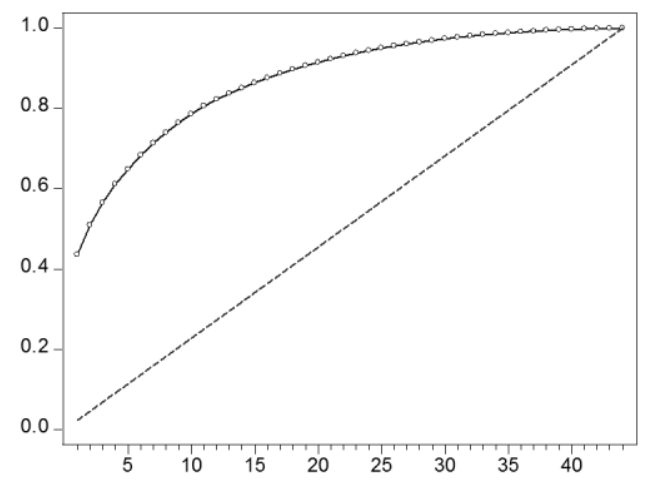

Figure 2: Cumulative Variance Proportion 
The first five eigenvectors corresponding to the fifth's largest eigenvalues and the correlation among the respective Principal Component and the return of each country are presented in Table 4. The first Principal Component is an almost equally weighted index of the countries' equity returns. The correlation of this Component with each country, with the exception of Jordan, Pakistan and Sri-Lanka, is above 50\%. From the second to the fifth Component, due to signal alternation, we have a relation of contrast among countries. For example, the second Component, considering only the countries with more than $10 \%$ of correlation, detaches two distinct groups. The first one is composed by the countries from Western Europe, plus United States, Israel, Brazil and Turkey. The second group encompasses the emerging markets (with the exception of Brazil) plus the Asians countries. 
Table 4: First Five Eigenvectors and their Correlation with the Countries`Returns

\begin{tabular}{|c|c|c|c|c|c|c|c|c|c|c|}
\hline $\mathrm{R}$ & $\mathrm{e} 1$ & $\rho(e 1, R)$ & $\mathrm{e} 2$ & $\rho(e 2, R)$ & e3 & $\rho(\mathrm{e} 3, \mathrm{R})$ & $\mathrm{e} 4$ & $\rho(e 4, R)$ & e5 & $\rho(e 5, R)$ \\
\hline \multicolumn{11}{|l|}{ Developed } \\
\hline AUSTRALIA & 0.1301 & 0.8393 & 0.0048 & 0.0126 & 0.0619 & 0.1433 & 0.0321 & 0.0675 & -0.0196 & -0.0366 \\
\hline AUSTRIA & 0.1385 & 0.7266 & 0.0473 & 0.1016 & 0.1377 & 0.2593 & 0.0891 & 0.1521 & 0.0033 & 0.0050 \\
\hline BELGIUM & 0.1183 & 0.6930 & 0.0906 & 0.2172 & 0.1858 & 0.3906 & 0.0636 & 0.1213 & 0.0197 & 0.0335 \\
\hline CANADA & 0.1334 & 0.8340 & 0.0367 & 0.0940 & 0.0333 & 0.0746 & 0.0121 & 0.0246 & -0.0552 & -0.1001 \\
\hline DENMARK & 0.1069 & 0.7156 & 0.0872 & 0.2390 & 0.1181 & 0.2837 & 0.0567 & 0.1236 & 0.0147 & 0.0284 \\
\hline FINLAND & 0.1564 & 0.6088 & 0.2414 & 0.3847 & 0.0960 & 0.1340 & -0.0204 & -0.0258 & 0.1655 & 0.1867 \\
\hline FRANCE & 0.1183 & 0.7945 & 0.1164 & 0.3203 & 0.1167 & 0.2814 & -0.0083 & -0.0181 & 0.0138 & 0.0270 \\
\hline GERMANY & 0.1346 & 0.7787 & 0.1223 & 0.2898 & 0.1288 & 0.2674 & -0.0139 & -0.0262 & 0.0278 & 0.0466 \\
\hline GREECE & 0.1536 & 0.6631 & 0.1327 & 0.2345 & 0.0876 & 0.1357 & 0.1242 & 0.1745 & 0.1553 & 0.1944 \\
\hline HONG KONG & 0.1548 & 0.7524 & -0.1188 & -0.2364 & 0.0219 & 0.0382 & -0.0776 & -0.1227 & -0.0782 & -0.1102 \\
\hline IRELAND & 0.1102 & 0.6597 & 0.0927 & 0.2274 & 0.1175 & 0.2525 & 0.0739 & 0.1440 & 0.0323 & 0.0561 \\
\hline ITALY & 0.1171 & 0.6654 & 0.1320 & 0.3073 & 0.1218 & 0.2485 & 0.0471 & 0.0872 & 0.0510 & 0.0841 \\
\hline ISRAEL & 0.1039 & 0.5578 & 0.1298 & 0.2855 & -0.0397 & -0.0765 & -0.0116 & -0.0203 & -0.0399 & -0.0622 \\
\hline JAPAN & 0.0877 & 0.5808 & 0.0068 & 0.0183 & 0.0897 & 0.2132 & -0.0120 & -0.0258 & 0.0495 & 0.0950 \\
\hline NETHERLANDS & 0.1234 & 0.7987 & 0.0942 & 0.2496 & 0.1323 & 0.3072 & 0.0127 & 0.0267 & 0.0297 & 0.0557 \\
\hline NEW ZEALAND & 0.1292 & 0.7439 & -0.0069 & -0.0163 & 0.0709 & 0.1465 & -0.0265 & -0.0498 & 0.0709 & 0.1183 \\
\hline NORWAY & 0.1633 & 0.7955 & 0.0866 & 0.1726 & 0.1285 & 0.2246 & 0.0962 & 0.1526 & -0.0405 & -0.0572 \\
\hline PORTUGAL & 0.1123 & 0.6725 & 0.1062 & 0.2603 & 0.1314 & 0.2825 & 0.0628 & 0.1224 & 0.0755 & 0.1311 \\
\hline SINGAPORE & 0.1672 & 0.8163 & -0.1346 & -0.2690 & 0.0009 & 0.0016 & -0.0613 & -0.0973 & -0.0325 & -0.0459 \\
\hline SPAIN & 0.1333 & 0.7796 & 0.0985 & 0.2358 & 0.1366 & 0.2867 & 0.0180 & 0.0343 & -0.0293 & -0.0497 \\
\hline SWEDEN & 0.1577 & 0.7800 & 0.1504 & 0.3047 & 0.1015 & 0.1801 & -0.0255 & -0.0410 & 0.0598 & 0.0857 \\
\hline SWITZERLAND & 0.0846 & 0.6724 & 0.0645 & 0.2098 & 0.1218 & 0.3476 & -0.0057 & -0.0148 & 0.0539 & 0.1243 \\
\hline UNITED KINGDOM & 0.0924 & 0.7952 & 0.0677 & 0.2385 & 0.0605 & 0.1870 & & 0.0520 & 0.0118 & 0.0295 \\
\hline USA & 0.0901 & 0.7867 & 0.0538 & 0.1923 & 0.0540 & 0.1692 & -0.0276 & -0.0784 & -0.0001 & -0.0004 \\
\hline \multicolumn{11}{|l|}{ Emerging } \\
\hline BRAZIL & 0.2310 & 0.7552 & 0.0794 & 0.1063 & & -0.1456 & 0.2194 & 0.2335 & -0.2394 & -0.2269 \\
\hline CHILE & 0.1359 & 0.7387 & -0.0458 & -0.1018 & -0.0620 & -0.1209 & 0.0407 & 0.0719 & -0.0921 & -0.1452 \\
\hline CHINA & 0.1762 & 0.6295 & -0.1862 & -0.2723 & -0.0708 & -0.0908 & -0.0904 & -0.1051 & -0.3158 & -0.3271 \\
\hline COLOMBIA & 0.1298 & 0.5224 & -0.0191 & -0.0315 & -0.1284 & -0.1855 & 0.0696 & 0.0911 & 0.0750 & 0.0874 \\
\hline INDIA & 0.1489 & 0.6322 & -0.0068 & -0.0119 & -0.0809 & -0.1233 & 0.1155 & 0.1596 & 0.1237 & 0.1523 \\
\hline INDONESIA & 0.2396 & 0.6623 & -0.4119 & -0.4663 & 0.0645 & 0.0640 & -0.1511 & -0.1360 & 0.2128 & 0.1705 \\
\hline KOREA & 0.1888 & 0.6332 & -0.1359 & -0.1867 & 0.0988 & 0.1189 & -0.1117 & -0.1220 & 0.3201 & 0.3113 \\
\hline MALAYSIA & 0.1412 & 0.5973 & -0.2438 & -0.4224 & -0.0273 & -0.0415 & -0.1176 & -0.1619 & 0.0627 & 0.0769 \\
\hline MEXICO & 0.1805 & 0.7398 & 0.0234 & 0.0393 & -0.0670 & -0.0986 & 0.0939 & 0.1253 & -0.2012 & -0.2390 \\
\hline PERU & 0.1612 & 0.6377 & -0.0299 & -0.0484 & -0.0424 & -0.0601 & 0.1828 & 0.2355 & -0.2612 & -0.2996 \\
\hline PHILIPPINE & 0.1507 & 0.6183 & -0.2737 & -0.4598 & 0.0197 & 0.0290 & -0.1362 & -0.1819 & -0.0399 & -0.0475 \\
\hline POLAND & 0.2266 & 0.6509 & 0.1083 & 0.1274 & 0.0479 & 0.0494 & 0.0988 & 0.0924 & 0.1932 & 0.1610 \\
\hline SOUTH AFRICA & 0.1625 & 0.7586 & -0.0461 & -0.0881 & 0.0265 & 0.0445 & -0.0092 & -0.0140 & -0.0634 & -0.0858 \\
\hline TAIWAN & 0.1545 & 0.6497 & -0.1173 & -0.2020 & -0.0293 & -0.0442 & -0.0564 & -0.0772 & -0.1340 & -0.1634 \\
\hline THAILAND & 0.2139 & 0.6820 & -0.3823 & -0.4991 & 0.0230 & 0.0263 & -0.1480 & -0.1536 & 0.0673 & 0.0622 \\
\hline TURKEY & 0.2583 & 0.6115 & 0.4186 & 0.4059 & -0.5508 & -0.4681 & -0.5995 & -0.4621 & 0.0547 & 0.0376 \\
\hline \multicolumn{11}{|l|}{ Frontier } \\
\hline ARGENTINA & 0.1916 & 0.6424 & 0.0191 & 0.0262 & -0.1050 & -0.1263 & 0.1361 & 0.1485 & -0.4971 & -0.4832 \\
\hline JORDAN & 0.0438 & 0.2994 & 0.0097 & 0.0272 & 0.0113 & 0.0278 & 0.0529 & 0.1178 & 0.1029 & 0.2040 \\
\hline PAKISTAN & 0.0826 & 0.2668 & -0.0938 & -0.1240 & -0.5571 & -0.6459 & 0.4312 & 0.4535 & 0.3465 & 0.3245 \\
\hline SRI LANKA & 0.1043 & 0.3881 & -0.0615 & -0.0937 & -0.1930 & -0.2578 & 0.3820 & 0.4627 & 0.1220 & 0.1316 \\
\hline
\end{tabular}




\subsubsection{Statistical risk factors from principal component analysis}

The Principal Components can be understood as information that summarizes the covariance structure of the data. However, it's not clear how to interpret this information. Following Campbell, Lo and Mackinlay (1997), we can normalize the eigenvectors so that their sum is equal to one. That means, let $w_{i}=e i /\left(\sum_{j=1}^{44} e_{i j}\right), i=1,2,3,4,5$, and the normalized Components will be $Y_{i}^{*}=\left(\frac{e_{i}}{\sum_{j=1}^{44} e_{i j}}\right)^{\prime} R=w_{i}^{\prime} R, i=1,2,3,4,5$. As $\sum_{j=1}^{44} w_{i j}=1$, the normalized Components are now portfolios of the countries equity indices whose weights add up to one. From the geometric point of view, this normalization causes a distortion of the Components, but doesn't alter its direction, preserving all the correlation relations contained in the original components.

The countries' portfolios formed by the normalized Principal Components still point the directions of greater variability of the original return data. For that reason, we are going to regard these portfolios as risk factors to be included in our model. They will be denominated statistical factors, $f_{i}, i=1,2,3,4,5$, to distinguish them from the macroeconomic factors. However, before presenting the model's empirical results, we will investigate the relation, if any exists, between statistical and macroeconomic factors.

\subsection{Relation Between Statistical and Macroeconomic Factors}

First of all, in Table 5 we present the descriptive statistics for the five statistical factors, $\mathrm{f}_{1}, \mathrm{f}_{2}, \mathrm{f}_{3}$, $\mathrm{f}_{4}$ e $\mathrm{f}_{5}$, and for the five macroeconomic factors, excess return of the world portfolio (world), logarithm variation on the Major Index (major), logarithm variation on the OITP Index (oitp), change in the spread between 90 day Eurodollar tax and the 90 day US Treasury bill yield (ted) and excess change in the oil price (oil). The mean and standard deviation are annualized. 
Table5: Descripitive Statisticals for Macroeconomic and Statistical Factors

\begin{tabular}{lrrlllllr}
\hline & Mean & $\begin{array}{r}\text { Standard } \\
\text { Deviation }\end{array}$ & \multicolumn{1}{l}{$\rho 1$} & \multicolumn{1}{l}{$\rho 2$} & $\rho 3$ & $\rho 4$ & $\rho 12$ & \multicolumn{1}{c}{$\rho 24$} \\
\hline \hline f1 & $5.89 \%$ & $21.22 \%$ & $0.256 *$ & 0.093 & 0.068 & 0.082 & -0.005 & 0.000 \\
f2 & $55.80 \%$ & $179.49 \%$ & $0.234^{*}$ & 0.108 & 0.096 & -0.037 & -0.067 & -0.002 \\
f3 & $2.40 \%$ & $102.97 \%$ & -0.038 & 0.011 & 0.057 & -0.037 & -0.048 & -0.013 \\
f4 & $8.89 \%$ & $53.43 \%$ & -0.026 & 0.103 & -0.011 & 0.069 & 0.027 & -0.010 \\
f5 & $1.02 \%$ & $103.78 \%$ & 0.040 & $-0.170 *$ & 0.027 & 0.018 & -0.082 & -0.008 \\
world & $3.87 \%$ & $15.80 \%$ & $0.185^{*}$ & 0.012 & 0.093 & 0.116 & 0.046 & 0.023 \\
major & $0.26 \%$ & $5.67 \%$ & $0.326 *$ & -0.030 & -0.047 & 0.096 & -0.099 & -0.027 \\
oitp & $0.12 \%$ & $4.39 \%$ & $0.290^{*}$ & 0.023 & -0.085 & -0.074 & -0.008 & 0.010 \\
ted & $0.19 \%$ & $0.20 \%$ & $0.288 *$ & $0.373 *$ & $0.343 *$ & $0.274 *$ & $0.192 *$ & 0.069 \\
oil & $5.00 \%$ & $29.18 \%$ & $0.244 *$ & 0.111 & 0.068 & -0.039 & -0.041 & -0.030 \\
\hline
\end{tabular}

In Table6, we show the correlation matrix for statistical and macroeconomic factors. By construction, the statistical factors have zero correlation between them. The first statistical factor has $90 \%$ correlation with the excess return of the market portfolio and $53 \%$ correlation with the change in the oitp index. The $90 \%$ correlation really stands out. This means that the first Principal Component - the one with higher capacity to explain the covariance structure of the returns (around 44\%) - have a strong relationship with the market portfolio.

Table6: Correlation Among Factors

\begin{tabular}{lrrrrrrrrrr}
\hline & $\mathrm{f} 1$ & $\mathrm{f} 2$ & $\mathrm{f} 3$ & $\mathrm{f} 4$ & $\mathrm{f} 5$ & world & major & oitp & ted & oil \\
\hline $\mathrm{f} 1$ & 1.000 & & & & & & & & & \\
$\mathrm{f} 2$ & 0.000 & 1.000 & & & & & & & & \\
$\mathrm{f} 3$ & 0.000 & 0.000 & 1.000 & & & & & & & \\
$\mathrm{f} 4$ & 0.000 & 0.000 & 0.000 & 1.000 & & & & & & \\
$\mathrm{f} 5$ & 0.000 & 0.000 & 0.000 & 0.000 & 1.000 & & & & & \\
world & 0.904 & 0.188 & 0.209 & -0.024 & 0.022 & 1.000 & & & & \\
major & 0.349 & -0.080 & 0.210 & -0.057 & 0.008 & 0.326 & 1.000 & & & \\
oitp & 0.526 & -0.207 & -0.018 & -0.046 & 0.085 & 0.386 & 0.331 & 1.000 & & \\
ted & -0.052 & -0.035 & -0.014 & -0.134 & -0.017 & -0.059 & -0.101 & 0.017 & 1.000 & \\
oil & 0.152 & -0.071 & 0.024 & 0.144 & -0.103 & 0.110 & 0.234 & 0.137 & -0.071 & 1.000 \\
\hline
\end{tabular}

In Table7 the linear projections of the statistical factors on the macroeconomic factors and a constant are presented, with robust standard deviation in brackets. The excess return of the world portfolio and the change in the OITP index are significant in the regressions with 
dependent variables $f_{1}, f_{2}, f_{3}$. The change in the Major index is significant only in the regression of $\mathrm{f}_{3}$. The change in the TED spread and the excess variation on the oil price are $10 \%$ significant, on the regression $\mathrm{f}_{4}$. It's interesting to note the $\mathrm{R}^{2}$ of 0.85 on the first regression. For the following regressions the $\mathrm{R}^{2}$ is considerably lower.

Table7: Linear Projection of the Statistical Factors on the Macroeconomic Factors

$f i=\beta 0+\beta 1$ world $+\beta 2$ major $+\beta 3$ oitp $+\beta 4$ ted $+\beta 5$ oil $+e i, i=1,2,3,4,5$.

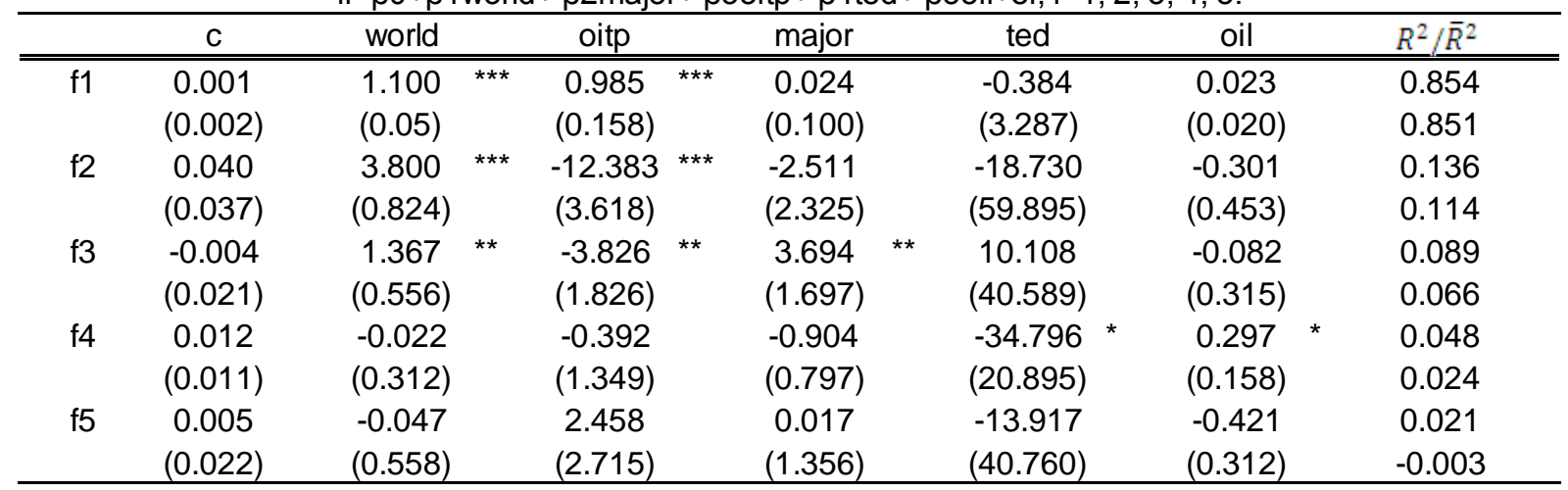

*** $1 \%$ significant, ${ }^{* *} 5 \%$ significant, ${ }^{*} 10 \%$ signifcant.

What we can obtain from this analysis is the great similarity between the first statistical factor and the world market portfolio. Recall that the statistical factors are just a rescaling of the Principal Components and that they preserve all the correlations relation of the latest. The world market portfolio is a weighted average of the countries returns based on the market value. The first Principal Component is also a weighted average of the countries portfolio, but the weights are obtained so that the first Principal Component points the direction of greater variability. This finding gives a justification for the importance of the world market portfolio in explaining the covariance structure of the countries returns. 


\section{EMPIRICAL RESULTS}

\subsection{Applying the model for three distinct groups of countries}

For a robustness analysis we selected three non-overlapping groups of ten countries - each containing 6 developed markets and the remainders four countries from emerging or frontier markets. Their composition, though arbitrarily, was chosen so that the three groups have a diversified geographic distribution, that is similar across the three groups, with the same proportion of developed and emerging countries. In figure 3, we show the composition of each group of countries. Group one is Argentina, Australia, Austria, Canada, China, Finland, Germany, Pakistan, Portugal and Taiwan. Group two is Belgium, Brazil, France, Hong Kong, Indonesia, Korea, Spain, Sri Lanka, Sweden and USA. Group three is Chile, Denmark, India, Italy, Japan, Malaysia, Mexico, New Zealand, Switzerland and United Kingdom

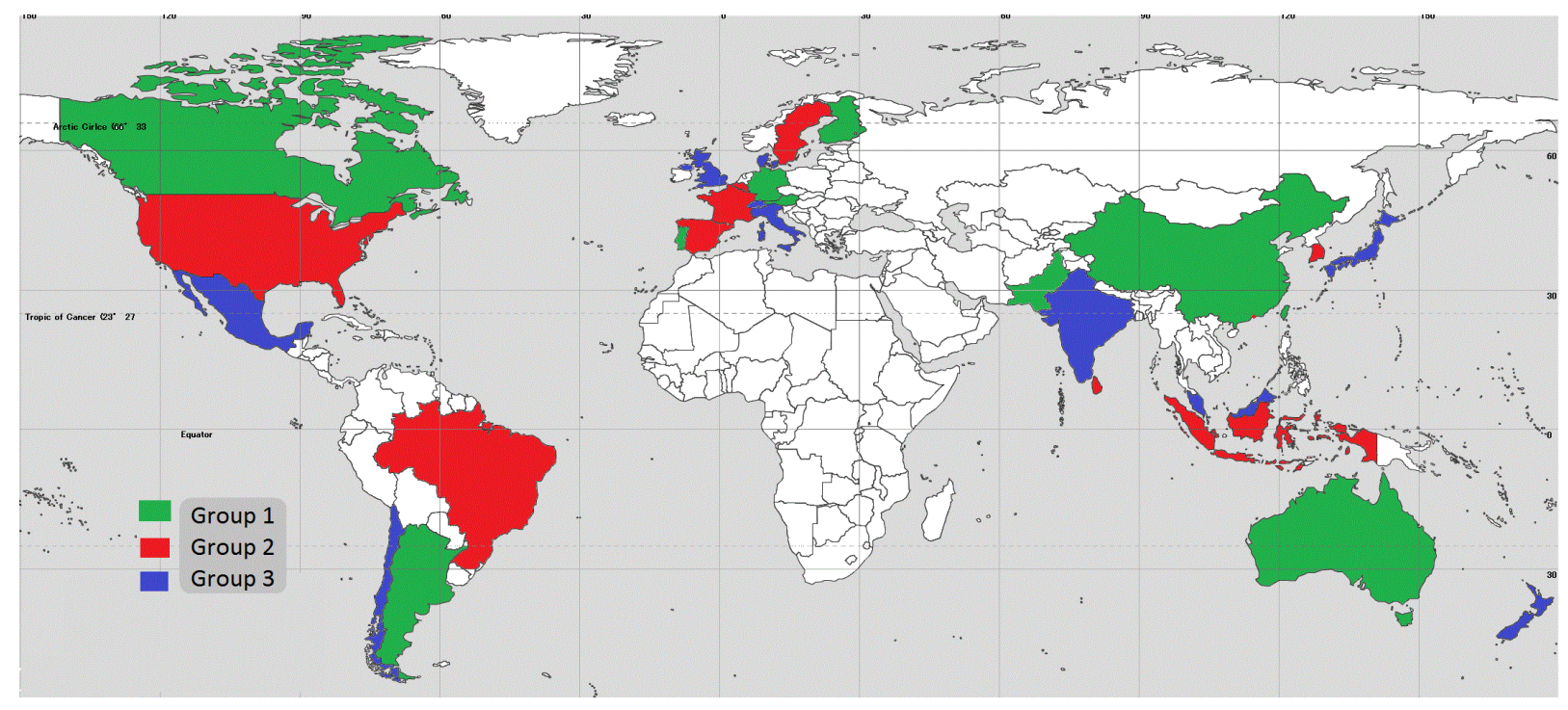

Figure 3: The Three Groups of Countries.

For each group an APT model using, separately, macroeconomic and statistical factors was estimated by both methodologies, ITNLSUR and GMM. In the GMM estimation we used as instruments the current risk factors and the lagged macroeconomic variables representing the available information for the investors.

A usual way to evaluate Asset Pricing Models, which will be applied here, is by their absolute pricing error (APE). This measure is obtained by the absolute value of the difference between the expected return delivered by the model, given by equation 2 , and the historical mean 
return given in Table 1. To visually analyze this difference we plotted the average historical return of the countries against the return predicted by the model and compared these points to the $45^{\circ}$ line.

For the GMM estimation we also use the J-statistic to test the over identifying restrictions.

\subsubsection{The Model with Macroeconomic Variables as Risk Factors}

Using macroeconomic variables, we tested the significance of the risk premiums for three different models. The option of which macroeconomic variable to include in each model was due to the importance of the variable in the relevant literature.

To start, Model 1 is a CAPM and has only the excess world return as risk factor. Model two includes also the exchange risk factors. Finally, Model 3 comprises all macroeconomic variables suggested earlier in section 5.

In Table 8 to Table 10 we show the estimated risk prices for each group by ITNLSUR and GMM. The table must be read in the horizontal. The first line of the table presents the results for the first model and so on. In APPENDIX 2, Figure 4 to Figure 6, we present the plot of the historical average return against the model`s predicted return.

One important result is that in the CAPM (Model 1), the world excess return is always priced. The premium varies from $0.4 \%$ to $0.5 \%$ per month, or $4.4 \%$ to $6.3 \%$ per year, and is significant at $1 \%$ in all groups, independent of the estimation method. The inclusion of other potential risk factors, however, can diminish or increase the significance of the world excess return.

The estimation of group one using ITNLSUR presents a significant risk premium for the oitp foreign exchange risk index. Nevertheless, when using GMM estimation for the same group the oitp risk premium isn't significant and major risk premium is.

Considering also group two and three, when we include other macroeconomic variables, besides the world excess of return, the results are very sensible to the group and estimation method. No pattern is observed. 
Comparing Figure 4 to Figure 6, we see that usually is ITNLSUR which presents the best fit. For groups two and three it's the model with all macroeconomic factors, estimated by ITNLSUR which reaches the minimum APE. As for group one, the model with all macroeconomic factors, estimated by ITNLSUR, is the second best and it is the model using three macroeconomic factors estimated by ITNLSUR which reaches the minimum.

For the GMM estimation we also performed the over identifying restrictions test. In all cases, the J-statistic reported in Table 11 indicates that we can't reject the null hypothesis that the over identifying restrictions equal zero. Consequently, we can't reject the specification of model 1 , 2 and 3 in any of the groups.

Table 8: Premia for the Macroeconomic Factors using Group 1.

\begin{tabular}{|c|c|c|c|c|c|c|}
\hline Method & Model & A_world & A_oitp & A_major & A_ted & A_oil \\
\hline \multirow{3}{*}{ ITNLSUR } & (1) & $\begin{array}{l}0.005^{\text {*** }} \\
0.001\end{array}$ & & & & \\
\hline & (2) & $\begin{array}{l}0.006^{* * *} \\
0.001\end{array}$ & $\begin{array}{c}-0.005 \text { * } \\
0.003\end{array}$ & $\begin{array}{r}-0.001 \\
0.004\end{array}$ & & \\
\hline & (3) & $\begin{array}{l}0.006^{* * *} \\
0.002\end{array}$ & $\begin{array}{c}-0.005 \text { * } \\
0.003\end{array}$ & $\begin{array}{r}-0.001 \\
0.004\end{array}$ & $\begin{array}{l}0.000 \\
0.000\end{array}$ & $\begin{array}{r}-0.001 \\
0.015\end{array}$ \\
\hline \multirow{3}{*}{ GMM } & (1) & $\begin{array}{l}0.005^{* * \star} \\
0.001\end{array}$ & & & & \\
\hline & (2) & $\begin{array}{l}0.004^{* * *} \\
0.001\end{array}$ & $\begin{array}{r}-0.001 \\
0.002\end{array}$ & $\begin{array}{l}0.012 \text { ** } \\
0.006\end{array}$ & & \\
\hline & (3) & $\begin{array}{l}0.002 \\
0.002\end{array}$ & $\begin{array}{l}0.001 \\
0.003\end{array}$ & $\begin{array}{l}0.011^{*} \\
0.006\end{array}$ & $\begin{array}{l}0.000 \text { * } \\
0.000\end{array}$ & $\begin{array}{l}0.018 \\
0.016\end{array}$ \\
\hline
\end{tabular}

${ }^{* * *} 1 \%$ significant, ${ }^{* *} 5 \%$ significant, ${ }^{*} 10 \%$ significant 
Table 9: Premia for the Macroeconomic Factors using Group 2.

\begin{tabular}{|c|c|c|c|c|c|c|}
\hline Method & Model & A_world & A_oitp & A_major & A_ted & A_oil \\
\hline \multirow{3}{*}{ ITNLSUR } & (1) & $\begin{array}{l}0.004^{* * *} \\
0.001\end{array}$ & & & & \\
\hline & (2) & $\begin{array}{l}0.004^{* * *} \\
0.001\end{array}$ & $\begin{array}{l}0.000 \\
0.002\end{array}$ & $\begin{array}{l}0.000 \\
0.003\end{array}$ & & \\
\hline & (3) & $\begin{array}{r}-0.002 \\
0.011\end{array}$ & $\begin{array}{l}0.006 \\
0.011\end{array}$ & $\begin{array}{r}-0.015 \\
0.027\end{array}$ & $\begin{array}{l}0.000 \\
0.001\end{array}$ & $\begin{array}{r}-0.245 \\
0.412\end{array}$ \\
\hline \multirow{3}{*}{ GMM } & (1) & $\begin{array}{l}0.004^{* * *} \\
0.000\end{array}$ & & & & \\
\hline & (2) & $\begin{array}{l}0.004^{* * *} \\
0.001\end{array}$ & $\begin{array}{l}0.002 \text { * } \\
0.001\end{array}$ & $\begin{array}{r}-0.002 \\
0.002\end{array}$ & & \\
\hline & (3) & $\begin{array}{l}0.003^{* * *} \\
0.001\end{array}$ & $\begin{array}{l}0.003 \text { * } \\
0.001\end{array}$ & $\begin{array}{c}-0.005 \text { * } \\
0.003\end{array}$ & $\begin{array}{l}0.000 \\
0.000\end{array}$ & $\begin{array}{r}-0.023 \\
0.017\end{array}$ \\
\hline
\end{tabular}

${ }^{* * *} 1 \%$ significant, ${ }^{* *} 5 \%$ significant, ${ }^{*} 10 \%$ significant 
Table 10 Premia for the Macroeconomic Factors using Group 3.

\begin{tabular}{|c|c|c|c|c|c|c|}
\hline Method & Model & A_world & A_oitp & A_major & A_ted & A_oil \\
\hline \multirow{6}{*}{ ITNLSUR } & \multirow{2}{*}{ (1) } & $0.004^{* * *}$ & & & & \\
\hline & & 0.001 & & & & \\
\hline & \multirow{2}{*}{ (2) } & 0.004 ** & 0.001 & -0.001 & & \\
\hline & & 0.001 & 0.002 & 0.005 & & \\
\hline & \multirow{2}{*}{ (3) } & 0.001 & 0.003 & 0.011 & -0.001 & -0.029 \\
\hline & & 0.003 & 0.003 & 0.011 & 0.000 & 0.033 \\
\hline \multirow{6}{*}{ GMM } & \multirow{2}{*}{ (1) } & $0.004^{* * *}$ & & & & \\
\hline & & 0.001 & & & & \\
\hline & \multirow{2}{*}{ (2) } & $0.007^{* * *}$ & 0.001 & $-0.031 * *$ & & \\
\hline & & 0.003 & 0.003 & 0.014 & & \\
\hline & \multirow{2}{*}{ (3) } & 0.003 & 0.001 & 0.003 & $-0.001 * *$ & $-0.043^{* * *}$ \\
\hline & & 0.002 & 0.003 & 0.005 & 0.000 & 0.019 \\
\hline
\end{tabular}

${ }^{* * *} 1 \%$ significant, ${ }^{* *} 5 \%$ significant, ${ }^{*} 10 \%$ significant

Table 11: Over identifying restrictions test.

The J-statistic for the $95 \%$ quantile and for each model

\begin{tabular}{lccc}
\hline \multicolumn{1}{c}{ Models } & CAPM & $\begin{array}{c}\text { World return, } \\
\text { OITP, MAJOR }\end{array}$ & $\begin{array}{c}\text { All Macro } \\
\text { Factors }\end{array}$ \\
degrees of freedom & $\mathbf{5 9}$ & $\mathbf{5 7}$ & $\mathbf{5 5}$ \\
critical value (95\% quantile) & $\mathbf{7 7 . 9 3}$ & $\mathbf{7 5 . 6 2}$ & $\mathbf{7 3 . 6 1}$ \\
\hline \hline J - group one & 58.98 & 57.40 & 51.23 \\
$\mathrm{~J}$ - group two & 70.07 & 60.11 & 71.80 \\
$\mathrm{~J}$ - group three & 59.42 & 51.93 & 45.93 \\
\hline
\end{tabular}

\subsubsection{The Model with Statistical Variables as Risk Factors}

Using the statistical factors extracted from Principal Components, we created five distinct models and tested the significance of the risk premiums. The first model is composed only of the first statistical factor. The second one covers the first and second statistical factors and so on. We ordered the inclusion of the factors according to its capacity of explaining the covariance structure of the data. 
In Table 12 to Table 14 we show the estimated risk prices for each group by ITNLSUR and GMM and in APPENDIX 2, Figure 7 to Figure 9, we present the plot of average historical return against the model's predicted return.

In the model with just one factor (Model 1), for the three groups, the first statistical factor has always a significant risk price. This premium varies from $0.5 \%$ to $0.6 \%$ per month or $6.2 \%$ to $7.5 \%$ per year. It is similar to the premium obtained in section 6 , for the model that considers only the world return as a risk factor. For Model 2 to Model 5, the inclusion of more statistical factors can diminish the significance of the first factor.

Other factors, depending on the model and the methodology of estimation, present significant risk premiums. However, the results aren't robust and no pattern is observed across groups.

Similar to the previous models, that used macroeconomic variables, with the statistical factors, it is also the ITNLSUR estimation which presents the smallest average APE. There is only one exception, the estimation of group two with one statistical factor, where the GMM methodology has a smaller APE than the ITNLSUR. The absolute pricing error, in general, shows a tendency to decline with the inclusion of more factors. However, the Absolute Pricing error of the models estimated using statistical risk factors are never smaller than the APE obtained from the previous estimation using the macroeconomic variables as risk factors.

As for the over identifying restriction test, the calculation of the J-statistic, reported in Table 15 usually indicates that we can't reject our model specification. However, there is one exception. In group two, using the model with three statistical factors (Model 3), we reject the spare restrictions at a $95 \%$ confidence level. 
Table 12: Premia for the Statistical Factors using Group 1.

\begin{tabular}{|c|c|c|c|c|c|c|}
\hline Method & Model & $\lambda \_f 1$ & $\lambda \_f 2$ & A_f3 & A_f4 & A_f5 \\
\hline \multirow{5}{*}{ ITNLSUR } & (1) & $\begin{array}{l}0.005^{* * *} \\
0.001\end{array}$ & & & & \\
\hline & (2) & $\begin{array}{l}0.004^{* * *} \\
0.001\end{array}$ & $\begin{array}{l}0.060 \\
0.043\end{array}$ & & & \\
\hline & (3) & $\begin{array}{l}0.004^{* * *} \\
0.001\end{array}$ & $\begin{array}{l}0.058 \\
0.050\end{array}$ & $\begin{array}{l}0.003 \\
0.020\end{array}$ & & \\
\hline & (4) & $\begin{array}{l}0.004^{* *} \\
0.002\end{array}$ & $\begin{array}{l}0.057 \\
0.054\end{array}$ & $\begin{array}{l}0.003 \\
0.031\end{array}$ & $\begin{array}{l}0.001 \\
0.021\end{array}$ & \\
\hline & (5) & $\begin{array}{l}0.005 * * \\
0.002\end{array}$ & $\begin{array}{l}0.040 \\
0.058\end{array}$ & $\begin{array}{l}0.000 \\
0.031\end{array}$ & $\begin{array}{r}-0.008 \\
0.024\end{array}$ & $\begin{array}{l}0.025 \\
0.024\end{array}$ \\
\hline \multirow{5}{*}{ GMM } & (1) & $\begin{array}{l}0.005^{* * *} \\
0.001\end{array}$ & & & & \\
\hline & (2) & $\begin{array}{l}0.004^{* * *} \\
0.001\end{array}$ & $\begin{array}{l}0.067 \text { * } \\
0.037\end{array}$ & & & \\
\hline & (3) & $\begin{array}{l}0.004^{* * *} \\
0.001\end{array}$ & $\begin{array}{l}0.068 \\
0.046\end{array}$ & $\begin{array}{l}0.000 \\
0.019\end{array}$ & & \\
\hline & (4) & $\begin{array}{l}0.003 \text { * } \\
0.002\end{array}$ & $\begin{array}{r}-0.034 \\
0.068\end{array}$ & $\begin{array}{l}0.061 \text { * } \\
0.035\end{array}$ & $\begin{array}{l}0.036 \text { * } \\
0.021\end{array}$ & \\
\hline & (5) & $\begin{array}{l}0.004 \text { * } \\
0.002\end{array}$ & $\begin{array}{l}0.016 \\
0.061\end{array}$ & $\begin{array}{l}0.031 \\
0.036\end{array}$ & $\begin{array}{l}0.015 \\
0.022\end{array}$ & $\begin{array}{l}0.006 \\
0.019\end{array}$ \\
\hline
\end{tabular}

${ }^{* * *} 1 \%$ significant, ${ }^{* *} 5 \%$ significant, ${ }^{*} 10 \%$ significant 
Table 13: Premia for the Statistical Factors using Group 2.

\begin{tabular}{|c|c|c|c|c|c|c|}
\hline Method & Model & A_f1 & $\lambda \_f 2$ & $\lambda \_f 3$ & $\lambda \_f 4$ & A_f5 \\
\hline \multirow{10}{*}{ ITNLSUR } & \multirow{2}{*}{ (1) } & $0.006^{* * *}$ & & & & \\
\hline & & 0.001 & & & & \\
\hline & \multirow{2}{*}{ (2) } & $0.006^{* * *}$ & 0.043 * & & & \\
\hline & & 0.001 & 0.025 & & & \\
\hline & \multirow{2}{*}{ (3) } & $0.006^{* * *}$ & 0.048 * & -0.016 & & \\
\hline & & 0.001 & 0.027 & 0.026 & & \\
\hline & \multirow{2}{*}{ (4) } & $0.006^{* * *}$ & 0.047 & -0.015 & 0.001 & \\
\hline & & 0.001 & 0.034 & 0.032 & 0.016 & \\
\hline & \multirow{2}{*}{ (5) } & $0.006^{* * *}$ & 0.036 & -0.008 & 0.001 & -0.027 \\
\hline & & 0.001 & 0.037 & 0.034 & 0.016 & 0.031 \\
\hline \multirow{10}{*}{ GMM } & \multirow{2}{*}{ (1) } & $0.006^{* * *}$ & & & & \\
\hline & & 0.001 & & & & \\
\hline & \multirow{2}{*}{$(2)$} & $0.006^{* * *}$ & 0.038 * & & & \\
\hline & & 0.001 & 0.021 & & & \\
\hline & \multirow{2}{*}{ (3) } & $0.007^{* * *}$ & $0.074^{* * *}$ & $-0.044 * *$ & & \\
\hline & & 0.001 & 0.021 & 0.020 & & \\
\hline & \multirow{2}{*}{ (4) } & $0.006^{* * *}$ & 0.061 ** & -0.033 & 0.010 & \\
\hline & & 0.001 & 0.027 & 0.024 & 0.012 & \\
\hline & \multirow{2}{*}{ (5) } & $0.005^{* * *}$ & 0.017 & 0.002 & 0.012 & -0.024 \\
\hline & & 0.001 & 0.036 & 0.030 & 0.014 & 0.026 \\
\hline
\end{tabular}

${ }^{* * *} 1 \%$ significant, ${ }^{* *} 5 \%$ significant, ${ }^{*} 10 \%$ significant 
Table 14: Premia for the Statistical Factors using Group 3.

\begin{tabular}{|c|c|c|c|c|c|c|}
\hline Method & Model & $\lambda \_f 1$ & A_f2 & A_f3 & $\lambda \_f 4$ & $\lambda \_f 5$ \\
\hline \multirow{5}{*}{ ITNLSUR } & (1) & $\begin{array}{l}0.005^{\text {*** }} \\
0.001\end{array}$ & & & & \\
\hline & (2) & $\begin{array}{l}0.005^{* * *} \\
0.001\end{array}$ & $\begin{array}{l}0.048 \\
0.041\end{array}$ & & & \\
\hline & (3) & $\begin{array}{l}0.005^{* * *} \\
0.001\end{array}$ & $\begin{array}{l}0.042 \\
0.051\end{array}$ & $\begin{array}{l}0.007 \\
0.036\end{array}$ & & \\
\hline & (4) & $\begin{array}{l}0.000 \\
0.004\end{array}$ & $\begin{array}{r}-0.245 \\
0.224\end{array}$ & $\begin{array}{l}0.156 \\
0.122\end{array}$ & $\begin{array}{l}0.160 \\
0.119\end{array}$ & \\
\hline & (5) & $\begin{array}{l}0.000 \\
0.004\end{array}$ & $\begin{array}{r}-0.250 \\
0.227\end{array}$ & $\begin{array}{l}0.164 \\
0.130\end{array}$ & $\begin{array}{l}0.157 \\
0.118\end{array}$ & $\begin{array}{r}-0.018 \\
0.072\end{array}$ \\
\hline \multirow{5}{*}{ GMM } & (1) & $\begin{array}{l}0.006^{* x *} \\
0.001\end{array}$ & & & & \\
\hline & (2) & $\begin{array}{l}0.006^{* * *} \\
0.001\end{array}$ & $\begin{array}{l}0.018 \\
0.035\end{array}$ & & & \\
\hline & (3) & $\begin{array}{l}0.005^{* * *} \\
0.001\end{array}$ & $\begin{array}{r}-0.054 \\
0.041\end{array}$ & $\begin{array}{l}0.071^{* *} \\
0.028\end{array}$ & & \\
\hline & (4) & $\begin{array}{l}0.002 \\
0.002\end{array}$ & $\begin{array}{l}-0.134^{* *} \\
0.060\end{array}$ & $\begin{array}{l}0.132 \text { *** } \\
0.044\end{array}$ & $\begin{array}{l}0.082 \text { * } \\
0.045\end{array}$ & \\
\hline & (5) & $\begin{array}{l}0.004^{* * *} \\
0.002^{*}\end{array}$ & $\begin{array}{r}-0.081 \\
0.052\end{array}$ & $\begin{array}{l}0.121^{* * *} \\
0.041\end{array}$ & $\begin{array}{l}0.025 \\
0.031\end{array}$ & $\begin{array}{r}-0.030 \\
0.034\end{array}$ \\
\hline
\end{tabular}

( ${ }^{* *} 1 \%$ significant, ${ }^{* *} 5 \%$ significant, ${ }^{*} 10 \%$ significant

Table 15: Overidentifying restrictions test.

The J-statistic for the $95 \%$ quantile and for each model

\begin{tabular}{lccccc}
\hline \multicolumn{1}{c}{ Models } & one factor & two factors & three factors & four factors & five factors \\
$\quad$ degrees of freedom & $\mathbf{5 9}$ & $\mathbf{5 8}$ & $\mathbf{5 7}$ & $\mathbf{5 6}$ & $\mathbf{5 5}$ \\
critical value (95\% quantile) & $\mathbf{7 7 . 9 3}$ & $\mathbf{7 6 . 7 8}$ & $\mathbf{7 5 . 6 2}$ & $\mathbf{7 4 . 4 7}$ & $\mathbf{7 3 . 3 1}$ \\
\hline \hline $\mathrm{J}$ - group one & 59.07 & 57.17 & 52.53 & 49.16 & 64.79 \\
$\mathrm{~J}$ - group two & 72.13 & 76.41 & 76.45 & 65.82 & 57.24 \\
$\mathrm{~J}$ - group three & 60.98 & 58.90 & 59.26 & 59.86 & 57.56 \\
\hline
\end{tabular}




\subsection{Applying the model for all 44 countries from our sample}

We applied the model ITNLSUR with macroeconomic factors ${ }^{11}$, which presented the best results (minimum APE) for the three groups, for all the 44 countries from our original sample. The results presented in Table 16 are consistent with what was presented for each previous group.

In the CAPM model the premium for the world excess return is $0.4 \%$ per month, or $4.5 \%$ per year, and is significant at $1 \%$. For the group of 44 countries, the inclusion of other potential risk factors has little impact over the significance of the world excess return.

The premium for the major Index (in model 2 and 3) and the premium for the TED spread are significant and negative, indicating that the price for taking the risk of these variables causes a decrease in expected returns. That contradicts the relation expected between risk and return in the presence of complete markets. However this can't be considered a robust result, since this behavior is not persistent in the three previous studied groups.

Analyzing APPENDIX 2, Figure 10, it can be seen that the inclusion of other variables, besides the world portfolio return, improves the fit of the model in relation to the initial CAPM.

Table 16: Premia for the Macroeconomic Factors using 44 countries

\begin{tabular}{|c|c|c|c|c|c|c|}
\hline Method & Model & A_world & 1_oitp & $\lambda \_m$ ajor & A_ted & A_oil \\
\hline \multirow{3}{*}{ ITNLSUR } & (1) & $\begin{array}{l}0.0037^{* * *} \\
0.0002\end{array}$ & & & & \\
\hline & (2) & $\begin{array}{l}0.0038^{* * *} \\
0.0003\end{array}$ & $\begin{array}{r}-0.0008 \\
0.0010\end{array}$ & $\begin{array}{c}-0.0031 \text { * } \\
0.0016\end{array}$ & & \\
\hline & (3) & $\begin{array}{l}0.0039^{* * *} \\
0.0003\end{array}$ & $\begin{array}{r}-0.0009 \\
0.0010\end{array}$ & $\begin{array}{l}-0.0031 \\
0.0017\end{array}$ & $\begin{array}{l}0.0002 \text { ** } \\
0.0001\end{array}$ & $\begin{array}{r}-0.0111 \\
0.0088\end{array}$ \\
\hline
\end{tabular}

${ }^{* * *} 1 \%$ significant, ${ }^{*} 5 \%$ significant, ${ }^{*} 10 \%$ significant

\footnotetext{
${ }^{11}$ Unfortunately, besides the model that uses ITNLSUR with Macroeconomic variables as risk factors, we were not able to apply for the group of all 44 countries the alternatives methodologies (ITNLSUR with statistical factors and GMM with macroeconomic and statistical factors). During the estimation process we faced a problem of near singular matrix. We have not found the source or this problem and, as a consequence, we could not solve it. That is a question unanswered left for future works.
} 


\section{CONCLUSIONS}

We developed an empirically analysis about the common sources of risk leading changes in equity returns of three non- overlapping groups of countries. Since each group was composed of very heterogeneous countries in relation to economic development, size, liquidity and market accessibility, two strategies were adopted in the attempt to encounter the potential sources of risk. In the first one, macroeconomic variables often cited in the relevant literature were used. In the second strategies, the risk factors were the portfolios - denominated statistical factors - constructed from a Principal Component Analysis using all 44 countries equity index available by MSCI.

The first result that draws the attention is the great resemblance between the first statistical factor and the world excess of return. The first statistical factor points the direction of greatest variability of the system containing the time series returns of the 44 markets. The world excess return is a market value weighted equity index of 24 developed markets and 21 emergent markets. In other words, these two indexes are constructed in distinct ways and, a priori, they would have nothing to do with each other. Nevertheless, they have a surprisingly correlation of over $90 \%$, their mean and standard deviation are of the same magnitude and, in a regression of the first statistical factor against all the macroeconomic factors, the coefficient of the world excess return is significant at $1 \%$. This finding gives a justification for the importance of the world market portfolio in explaining the covariance structure of the countries returns.

After presenting the risk factors, analyzing their characteristics and the relation among them, we use the statistical and macroeconomic variables separately as sources of risk factors in APT models, estimated by GMM or ITNLSUR, for three economically and geographically heterogeneous groups of ten countries.

In relation to previous works, our contribution is to include emerging and frontier markets combined with developed countries and study the sources of risk that are consistently priced in groups of diversified economy. Robust premiums across groups were observed only for the world excess return, in the model with macroeconomic factors, and for the first statistical factor, extracted from Principal Component Analysis. The premiums for the world's portfolio 
return and the first statistical factor was near 5\% per year for both variables. The others specified risk factors included in our model, although not consistently priced, helped reducing the absolute pricing error. The model which presented the best fit in all groups was the ITNLSUR with macroeconomic factors. However, following Hansen, Heaton and Yaron (1994), the worst fit of GMM can be attributed to its bad properties in small samples.

\subsection{Future Works:}

When we applied the ITNLSUR model with macroeconomic factors for our total sample of 44 countries the results were consistent with what was observed for the individual groups. In the CAPM the premium for the world excess return was close to $4 \%$ per year and this value slightly varied with the inclusion of other factors. The fit of the model was also improved with the inclusion of the other macroeconomic chosen factors. Unfortunately, we were not able to apply the other models - ITNLSUR with statistical factors and GMM with macroeconomic and statistical factors - proposed in this work for the entire sample of 44 countries due to a near singular matrix problem. That is a question left to be solved in future works.

Also, it would be interesting to repeat the estimation in the future when a bigger sample of countries' equity return will be available. The intention is to verify if the worst GMM's model fit is due to its bad properties in small sample and if it will overcome ITNLSUR's fit. 


\section{REFERENCES}

ADLER, Michael and DUMAS, Bernard. International Portfolio Choice and Corporation Finance: A Synthesis. The Journal of Finance, Volume XXXVIII, nº 3, 1983.

CAMPBELL, J. Y., LO, A. and MACKINLAY, C.: The Econometrics of Financial Markets. Princeton University Press, Princeton, 1997.

CARRIERI, Francesca, ERRUNZA, Vihang and MAJERBI, Basma. Global Price of Foreign Exchange Risk and the Local Factor. 2004.

CHEN, N.F., ROLL, R., and ROSS, S. A. Economic Forces and the Stock Market. Journal of Business, 59(3), 383-403, 1986.

FAMA, E. F., and FRENCH, K. R. Common risk factors in the returns on stocks and bonds. Chicago, Journal of Financial Economics, 3-56,1993.

FAMA, E. F and MACBETH, J. D. Risk, Return, and Equilibrium: Empirical Tests. The Journal of Political Economy, Vol. 81, No. 3. pp. 607-636, 1973.

FERSON, Wayne E. and HARVEY, Campbell R. The Risk and Predictability of International Equity Returns. The Review of Financial Studies, Volume 6, number 3, pp. 527-566, 1993.

FERSON, Wayne E. and HARVEY, Campbell R. Sources of Risk and Expected Returns in Global Equity Markets. Jounal of Banking and Finance 18, 775-803, 1994.

GIBBONS, Michael R. and FERSON, E. Wayne. Tests of Asset Pricing Model with Changing Expectations and an unobservable market Portfolio. Journal of Financial Economics, 14, 217-236, 1985.

HANSEN, Lars P. Large Sample Properties of Generalized Method of Moments Estimators. Econometrica, Volume 50, nº 4, pp. 1029-1054, 1982.

HANSEN, Lars P, HEATON, John and YARON, Amir Finite Sample Properties of Some Alternative GMM Estimators. Cambridge, 1994.

HANSEN, Lars P. and HODRICK, Robert J. Risk Averse Especulationin in Forward Foreign Exchange Markets: An econometric Analysis of Linear Model. University of Chicago Press, IL, In: Jacob A. Frenkel, ed., Exchange Rates and International Macroeconomics, 1983.

HARVEY, Campbell R. The World Price of Covariance Risk. Journal of Finance, Vol. 46, No.1, 111-157, 1991.

HARVEY, Campbell R., SOLNIK, Bruno and ZHOU, Guofu. What Determines Expected International Asset Returns?. Annal of Economics and Finance 3, 249-298, 2002. 
IKEDA, Shinsuke. Asset Pricing under Exchange Risk. Journal of Finance, Vol. 46, No. 1, 447-455, 1991.

JOHNSON, A. R. and WICHERN, W. D. Applied Multivariate Statistical Analysis. Pearson Education, 2007.

Lintner, J. The Valuation of Risky Assets and the Selection of Risky Investments in Stock Portfolios and Capital Budgets. Review of Economics and Statistics, 47, 13-37, 1965.

MCELROY, Marjorie B. e BURMEISTER, Edwin. Arbitrage Pricing Theory as a Restricted Nonlinear Multivariate Regression Model: Iterated Nonlinear Seemingly Unrelated Regression Model. Jounal of Business \& Economic Statistics, Vol 6., No. 1, 2942, 1988.

Roll, R. W. A Critique of the Asset Pricing Theory's Tests. Journal of Financial Economics, 4, 129-176, 1977.

ROLL, Richard, and ROSS, Stephen A. An empirical Investigation of the Arbitrage Pricing Theory. Journal of Finance, 35,1073-1103, 1980.

ROSS, Stephen A. The Arbitrage Theory of Capital Asset Pricing. Journal of Economic Theory, 13, 341-60, 1976.

SHARPE, W. F. Capital Asset Prices: A Theory of Market Equilibrium Under Conditions of Risk. Journal of Finance, 19, 425-442, 1964.

SOLNIK, Bruno. An equilibrium model of the international capital market. Journal of Economic Theory 8, 500-524, 1974.

SOLNIK, Bruno. International Arbitrage Pricing Theory. Journal of Finance, Vol. 38, No. 2, 449-457, 1983.

STULZ, Rene. A model of international asset pricing. Journal of Financial Economics 9, 383-406, 1981.

TREYNOR, J. L. Toward a Theory of Market Value of Risky Assets. 1961. 


\section{APPENDIX 1}

\section{The correlation matrix for the equity index.}

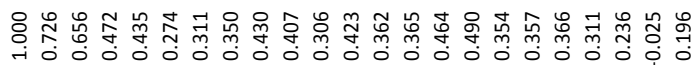

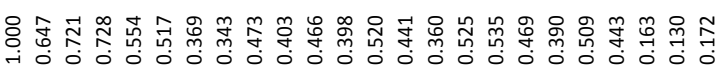

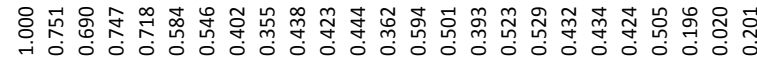

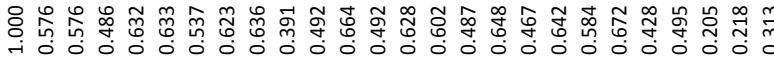

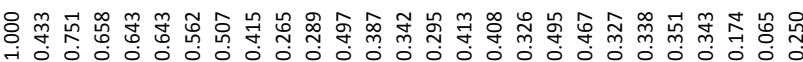

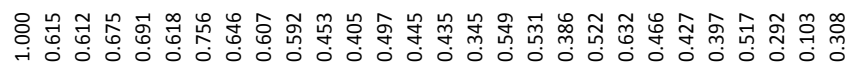

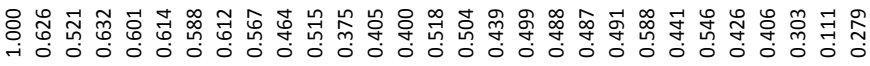

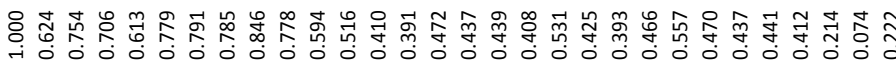

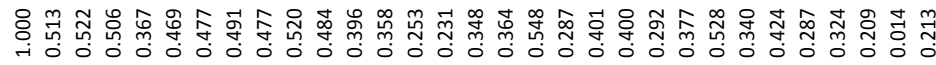

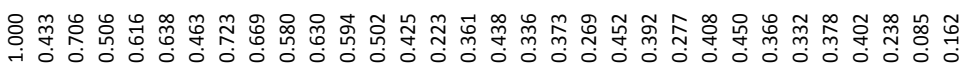

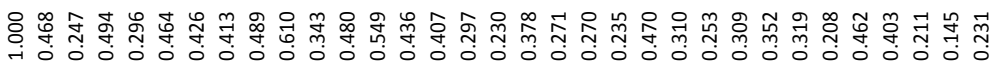

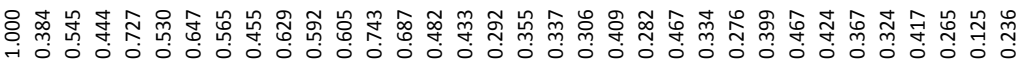

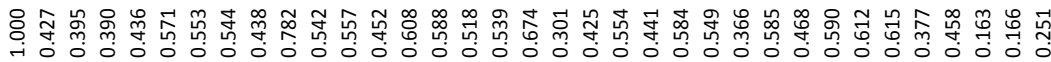

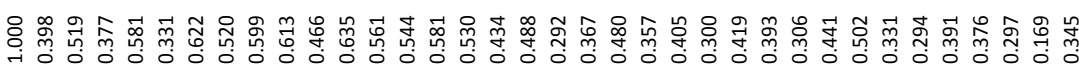

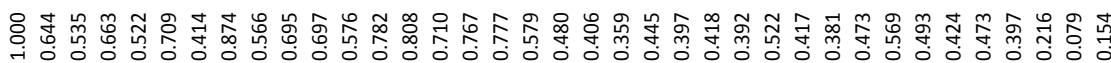

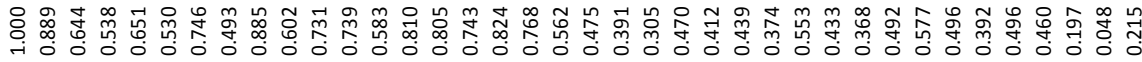

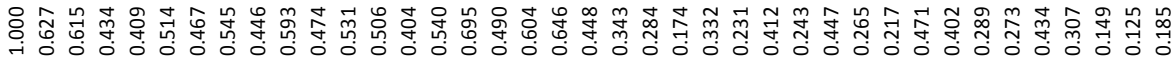

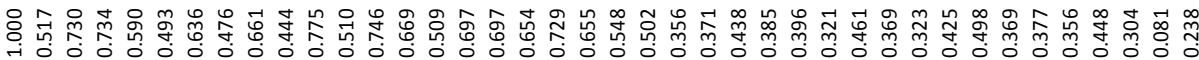

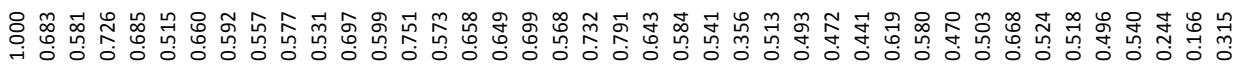

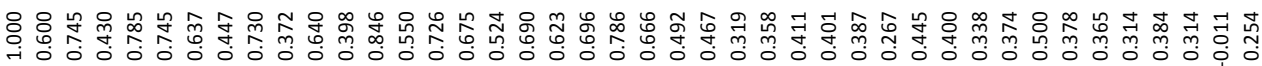

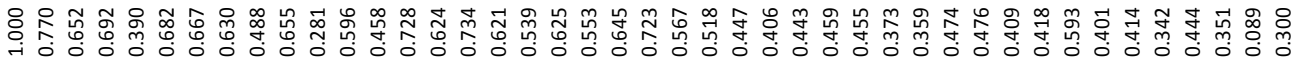

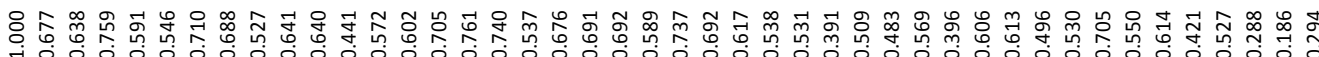

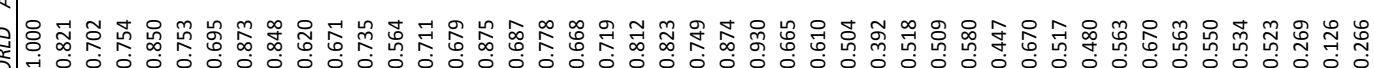
焉

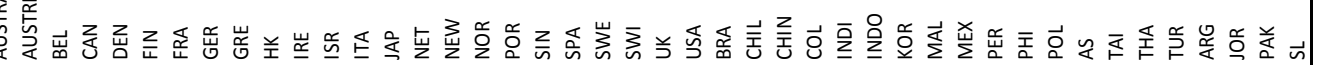




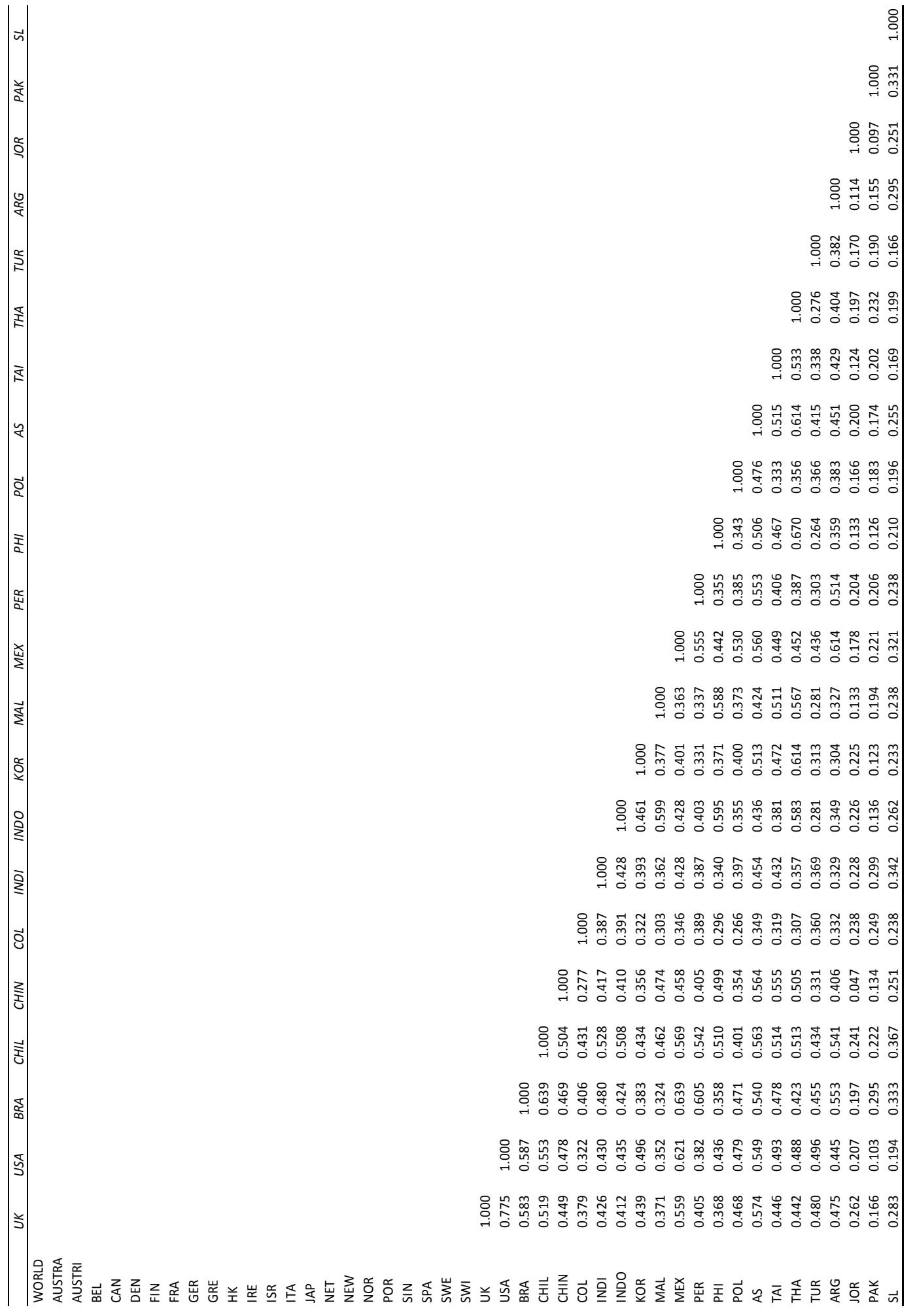




\section{APPENDIX 2}

Average Monthly Returns (x-axis) x Predicted Monthly Returns (y-axis)

Figure 4: Model's fit for Group 1 using Macroeconomic Factors
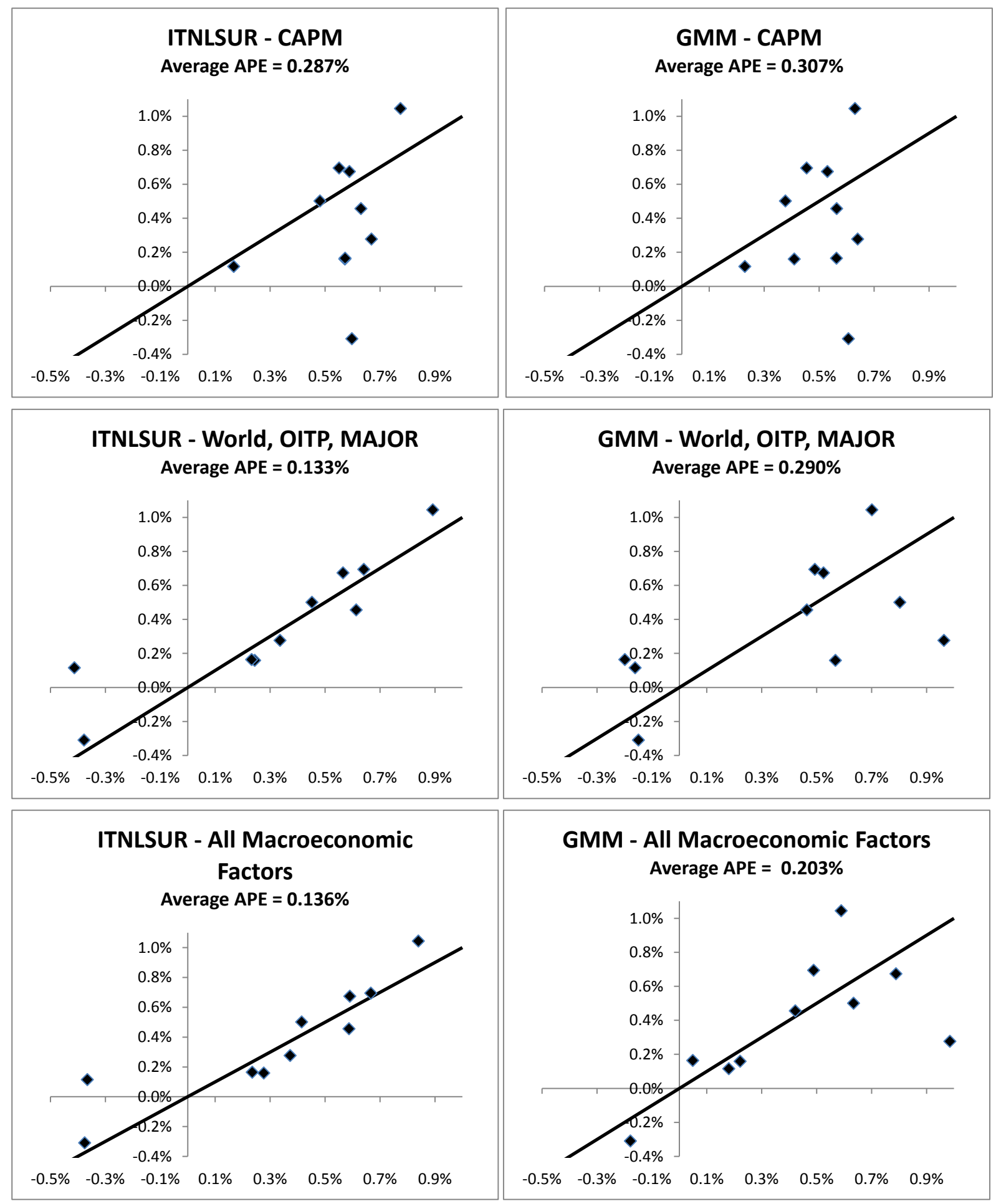
Figure 5: Model's fit for Group 2 using Macroeconomic Factors
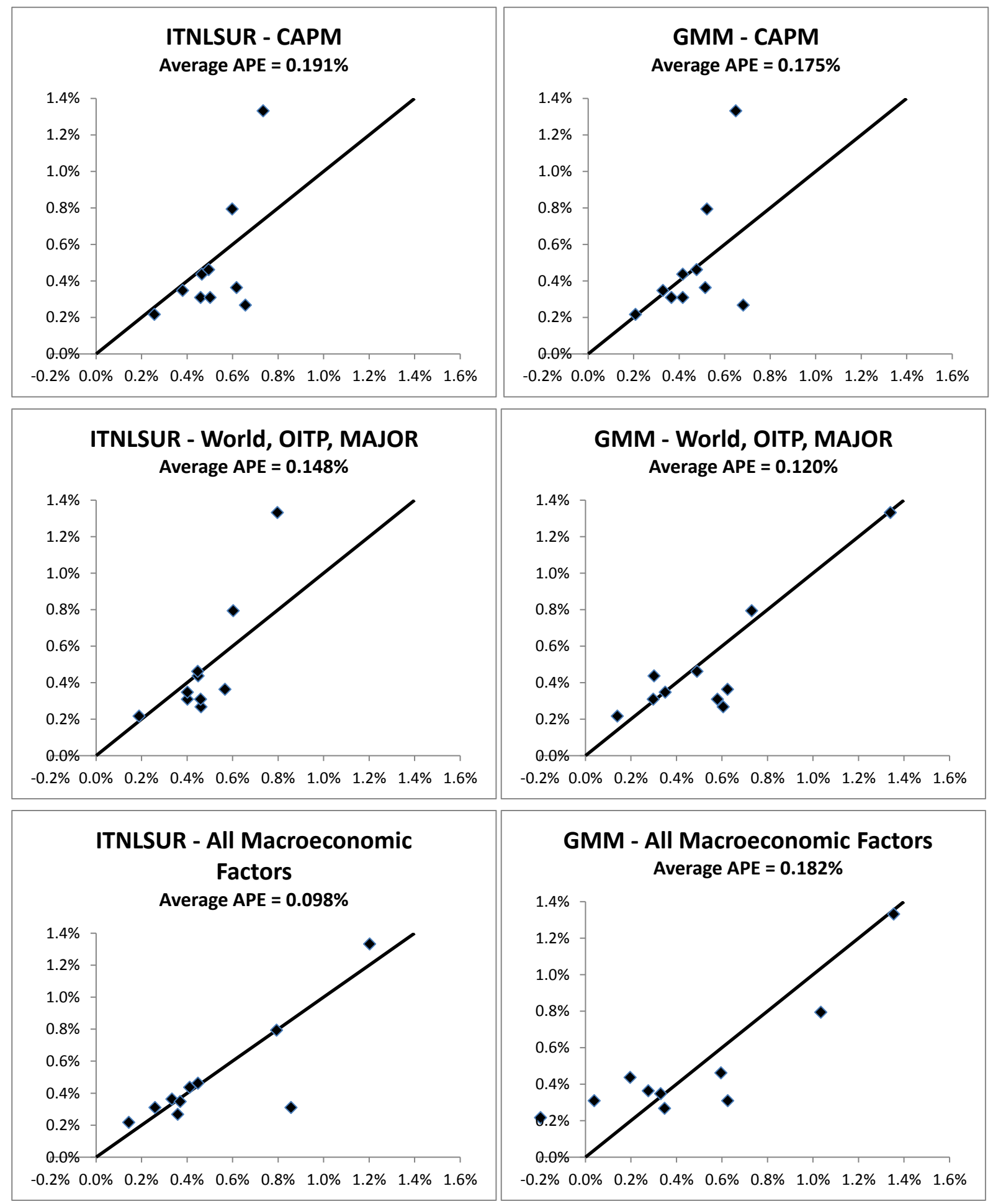
Figure 6: Model's fit for Group 3 using Macroeconomic Factors
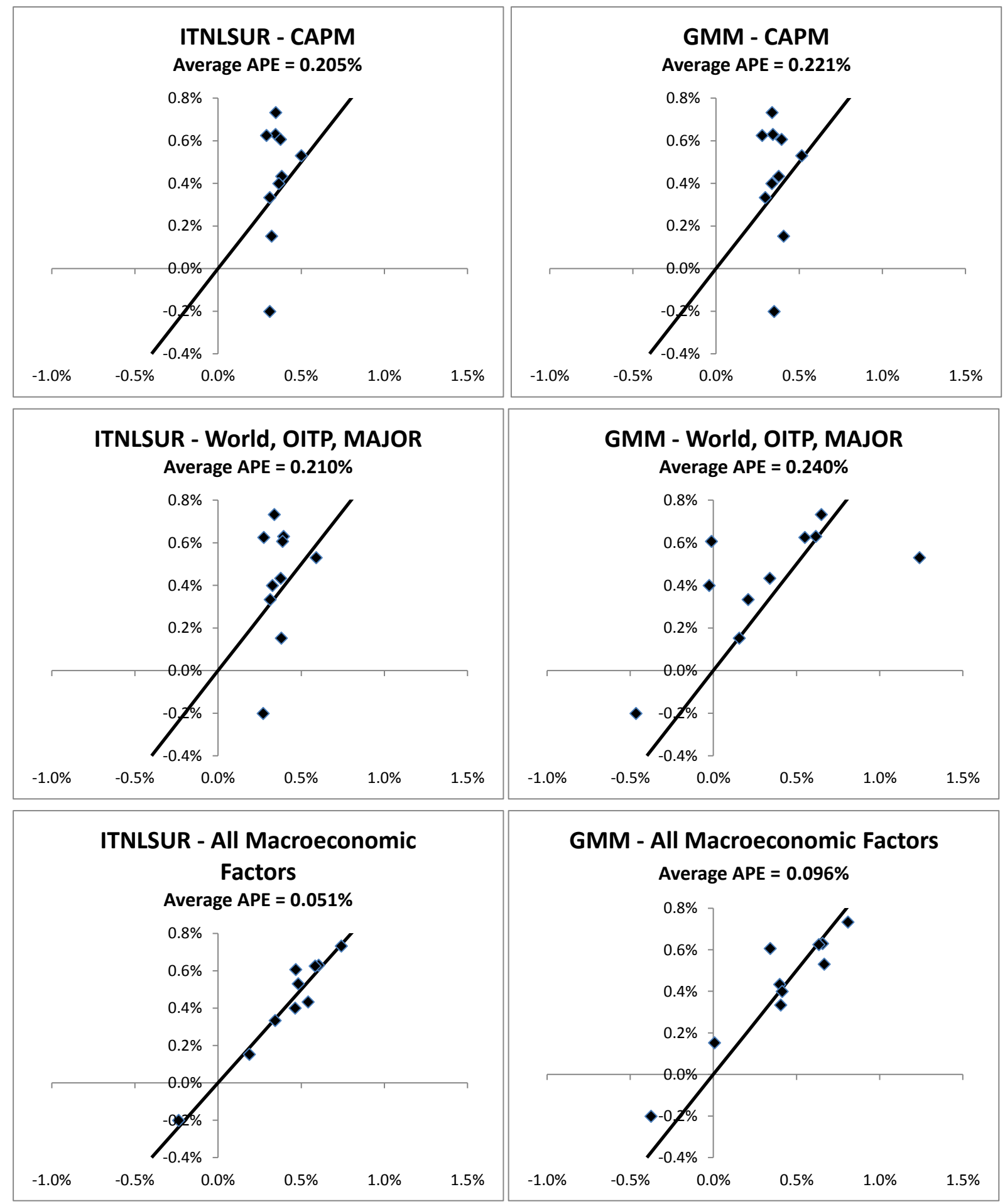
Figure 7: Model's fit for Group 1 using Statistical Factors

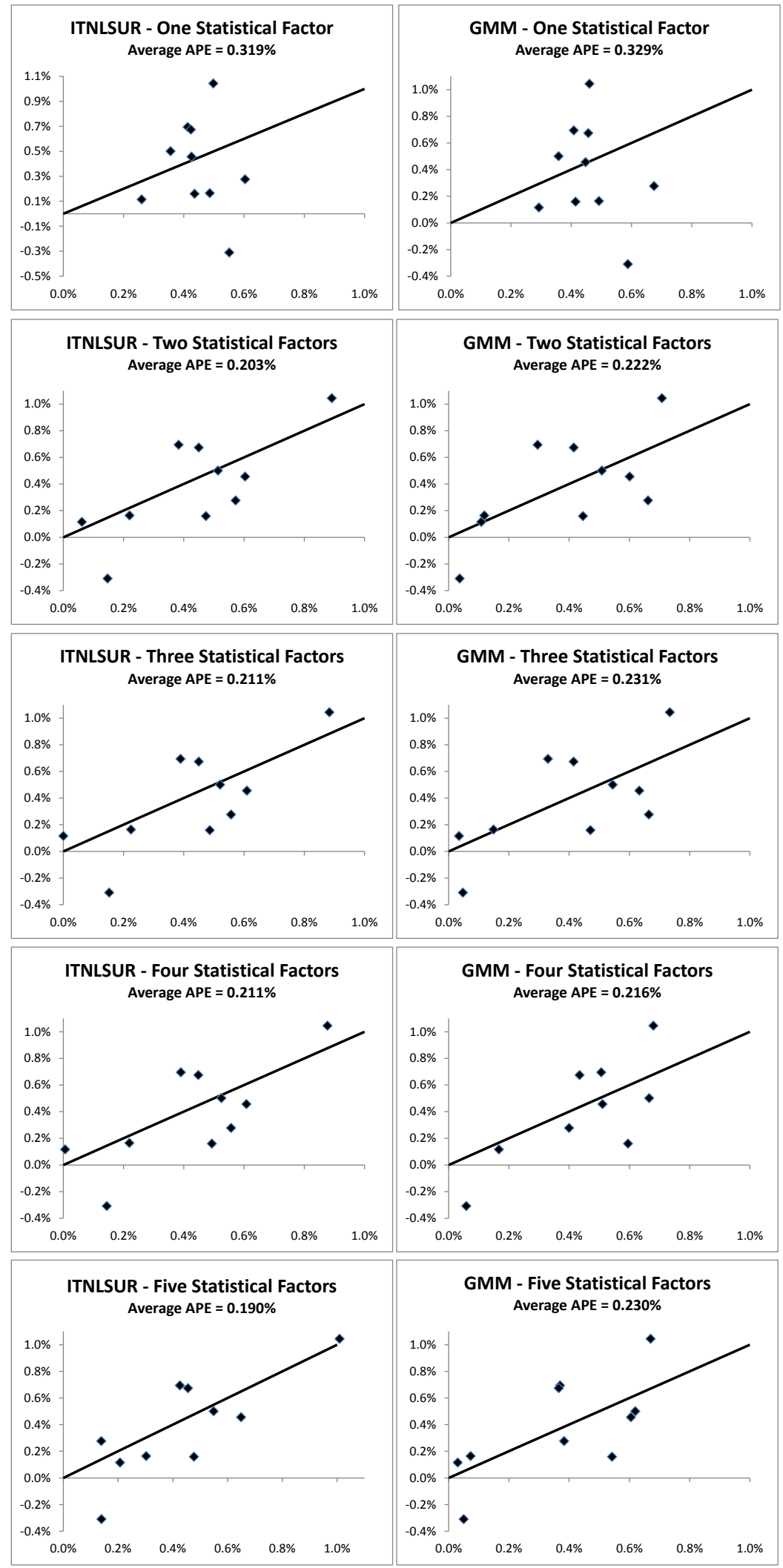


Figure 8: Model's fit for Group 2 using Statistical Factors

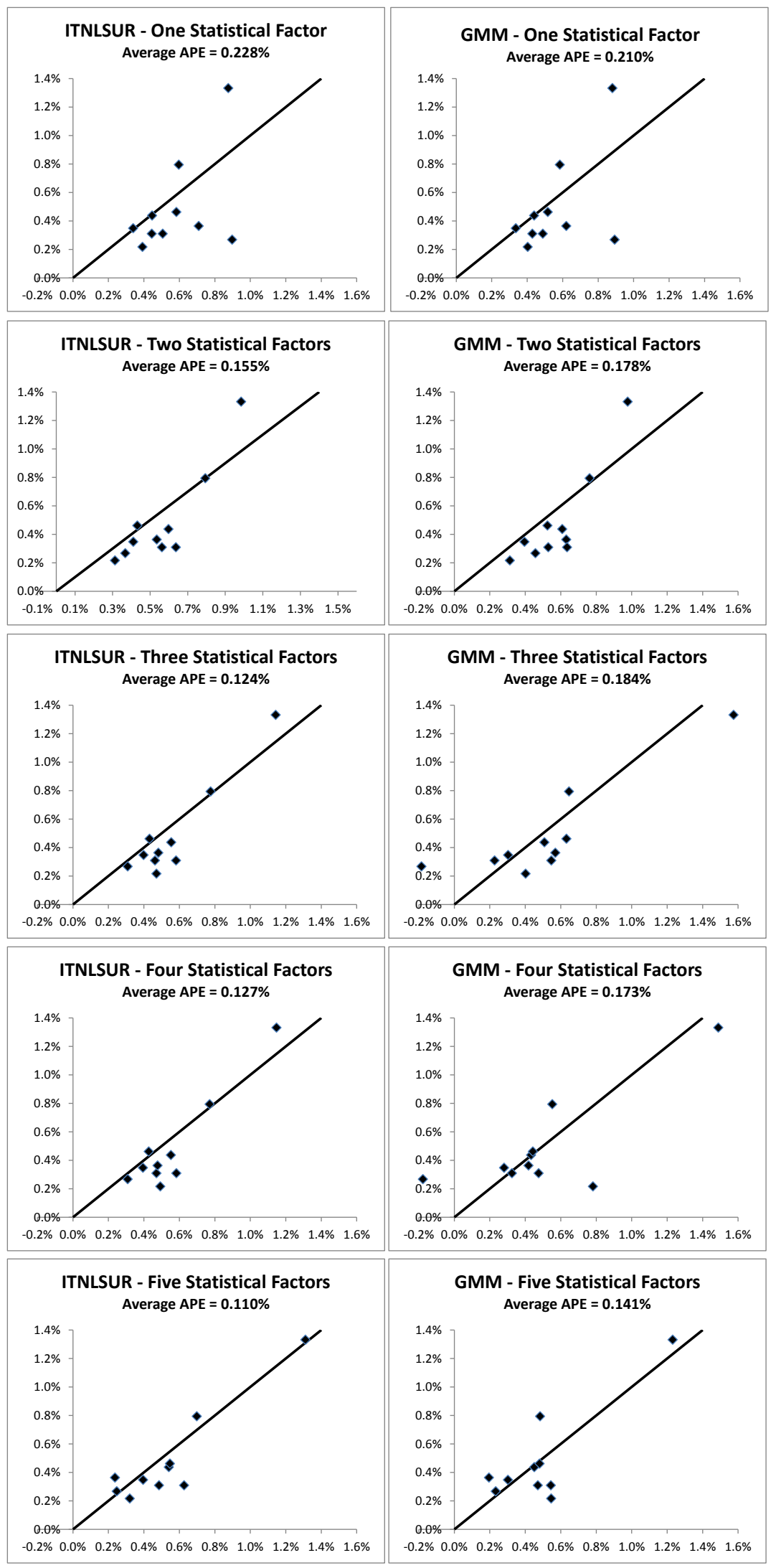


Figure 9: Model's fit for Group 3 using Statistical Factors
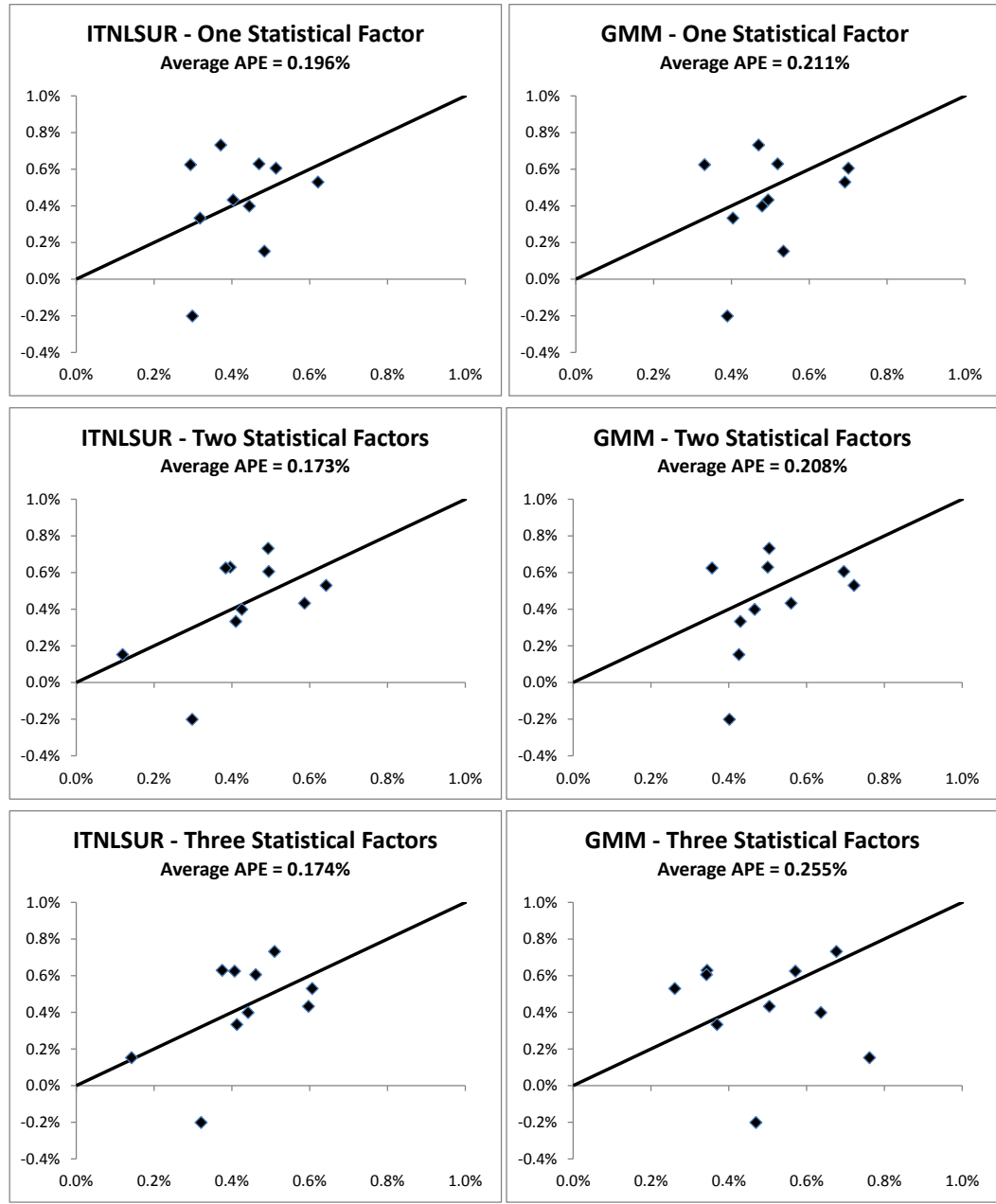

GMM - Three Statistical Factors Average APE $=0.255 \%$

ITNLSUR - Four Statistical Factors Average APE $=0.086 \%$
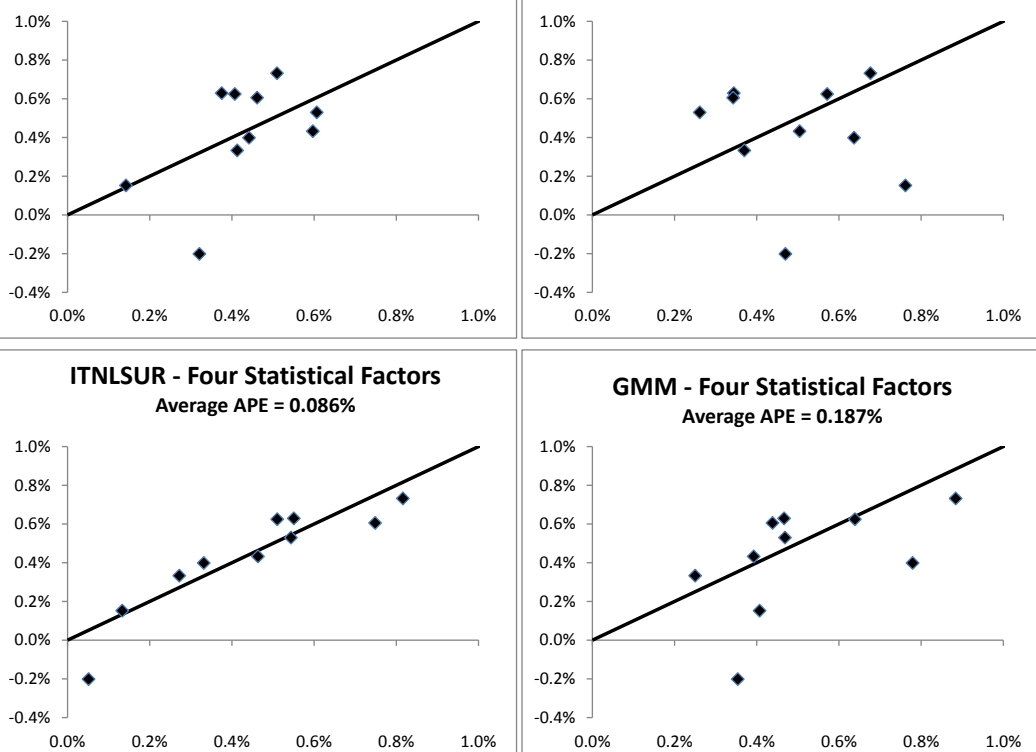

GMM - Four Statistical Factors Average APE $=0.187 \%$
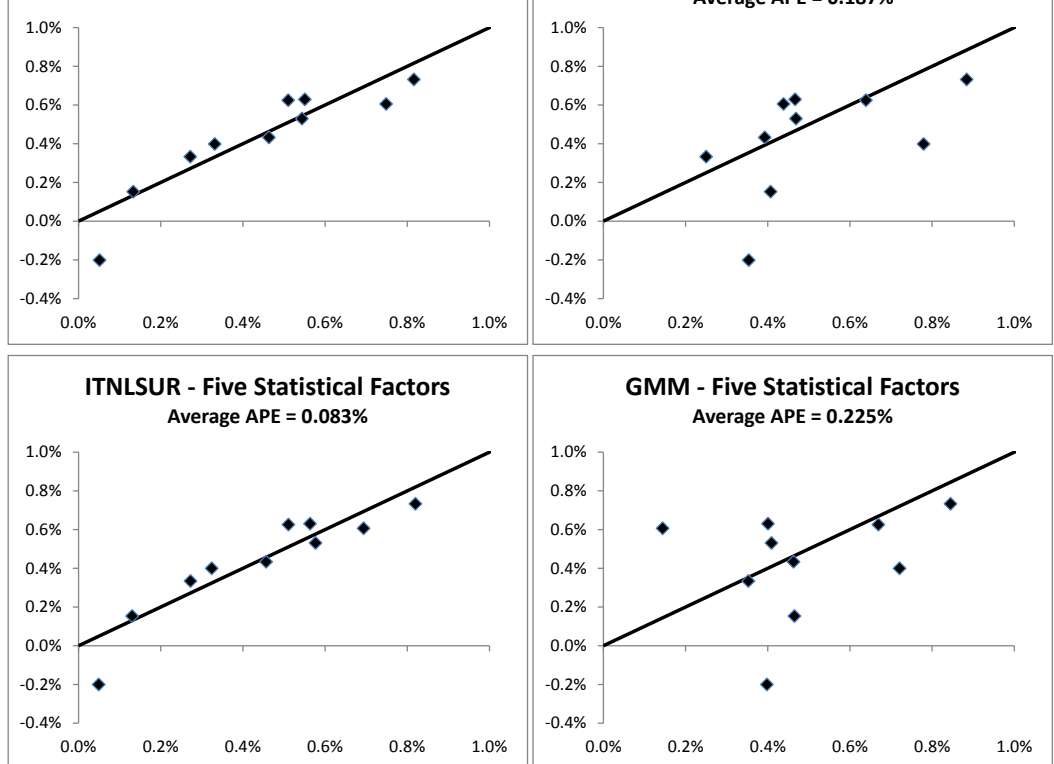

GMM - Five Statistical Factors Average APE $=0.225 \%$

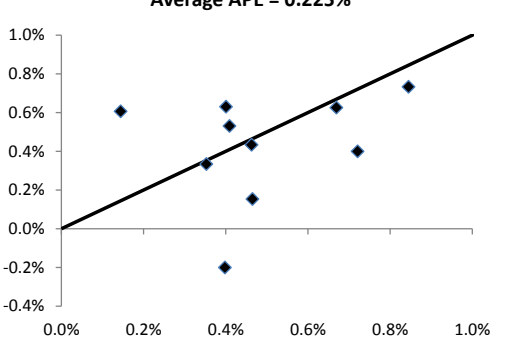


Figure 10: Model's fit for the 44 countries using Macroeconomic Factors
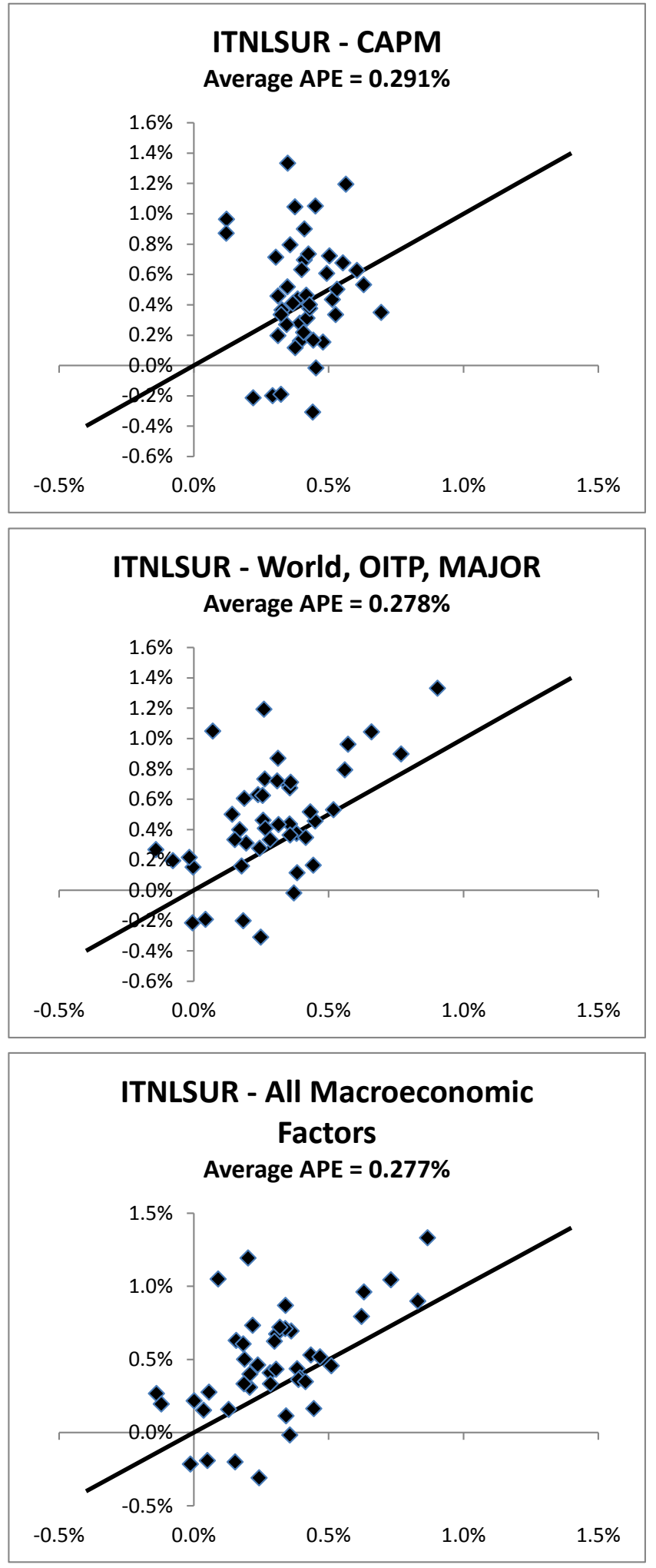